\title{
Structural studies near Pevek, Russia: implications for formation of the East Siberian Shelf and Makarov Basin of the Arctic Ocean
}

\author{
E. L. Miller ${ }^{1}$ and V. E. Verzhbitsky ${ }^{2}$ \\ ${ }^{1}$ Department of Geological and Environmental Sciences, Stanford University, Stanford, CA 94301, USA \\ ${ }^{2}$ Shirshov Institute of Oceanology, 36 Nakhimovsky prosp., Moscow, 117997, Russia
}

\begin{abstract}
The Pevek region of Arctic Russia provides excellent beach cliff exposure of sedimentary and igneous rocks that yield detailed information on the nature, progression and timing of structural events in this region. Regional folding and thrust faulting, with the development of a south-dipping axial plane cleavage/foliation developed during N-S to NESW directed shortening and formation of the ChukotkaAnyui fold belt. This deformation involves strata as young as Valanginian (136-140 Ma, Gradstein et al., 2004). Foldrelated structures are cut by intermediate to silicic batholiths, plutons and dikes of Cretaceous age. Reported K-Ar whole rock and mineral ages on the granitoids range from 144 to $85 \mathrm{Ma}$, but to the south, more reliable U-Pb zircon ages on compositionally similar plutons yield a much narrower age range of $\sim 120-105 \mathrm{Ma}$ (Miller et al., this volume) and a pluton in Pevek yields a U-Pb age on zircon of $108.1 \pm 1.1 \mathrm{Ma}$ with evidence for inheritance of slightly older $115 \mathrm{Ma}$ zircons. Magmas were intruded during an episode of E-W to ENE-WSW directed regional extension based on the consistent N-S to NNW-SSE orientation of over 800 mapped dikes and quartz veins. Analysis of small-offset faults and slickensides yield results compatible with those inferred from the dikes. Younger tectonic activity across this region is minor and the locus of magmatic activity moved southward towards the Pacific margin as represented by the $<90$ Ma OkhotskChukotsk volcanic belt (OCVB). A lengthy period of uplift and erosion occurred after emplacement of Cretaceous plutons and produced the peneplain beneath the younger OCVB.

Based on our studies, we speculate that $\sim 120-105 \mathrm{Ma}$ magmatism, which heralds a change in tectonic regime from compression to extension, could represent one of the consequences of the inception of rifting in the Amerasian Basin of the Arctic, forming the Makarov Basin north of the Siberian shelf at this longitude. A synthesis of available seismic reflection, gravity and magnetic data for the offshore Siberian
\end{abstract}

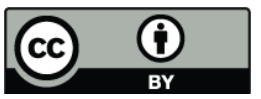

Correspondence to: E. L. Miller (elmiller@stanford.edu)
Shelf reveals a widespread, seismically mappable basementsedimentary cover contact that deepens northward towards the edge of the shelf with few other significant basins. Various ages have been assigned to the oldest strata above the unconformity, ranging from Cretaceous (Albian - 112-100 Ma) to Tertiary (Paleocene-Eocene $-\sim 60-50 \mathrm{Ma}$ ). The period of uplift and erosion documented along the Arctic coast of Russia at this longitude could represent the landward equivalent of the (yet undrilled) offshore basement-sedimentary cover contact, thus overlying sedimentary sequences could be as old as early Late Cretaceous. Although quite speculative, these conclusions suggest that land-based geologic, structural, petrologic and geochronologic studies could provide useful constraints to help resolve the plate tectonic history of the Arctic Ocean.

\section{Introduction}

The Arctic Ocean conceals one of the few unresolved plate tectonic puzzles on Earth, with important implications for the geologic history of the vast adjoining shelfal regions (Fig. 1). Until we are able to scientifically drill the most controversial parts of the Arctic Ocean seafloor, many questions about its origin will remain unanswered. This paper contributes to furthering our knowledge of the East Siberian Shelf and the adjacent Amerasian Basin of the Arctic Ocean by analyzing the nature, progression and timing of structural events along the Arctic coast of Russia. Although our data are land-based and can only be extrapolated in a very speculative fashion offshore, they provide broad constraints on the age and history of the seismically mapped acoustic basement-sedimentary cover sequence offshore and the rift history of the Makarov Basin part of the Amerasian Basin that lies to the north of the East Siberian Shelf at this longitude (Fig. 1). Prior to discussing our data and their interpretation, we briefly describe the tectonic features of the Arctic Ocean and the unresolved tectonic problems they present.

Published by Copernicus Publications on behalf of the European Geosciences Union. 


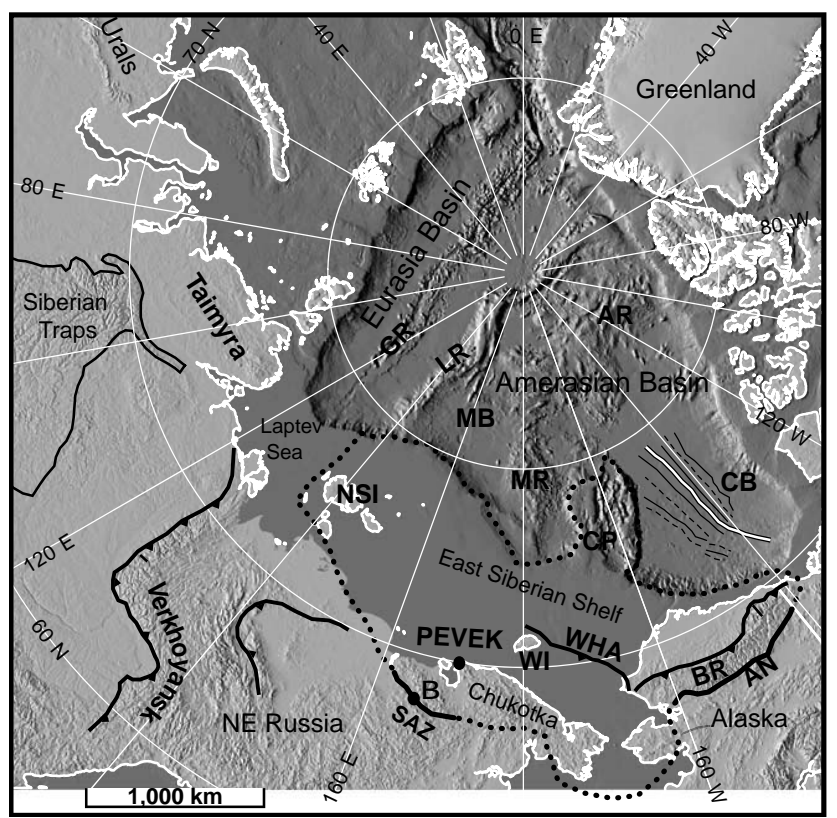

Fig. 1. Circum-Arctic map showing the location of the town of Pevek with respect to the main tectonic features of the Arctic Ocean. Bathymetry is from IBCAO (2002). The heavy dotted line marks the outline of the postulated Arctic Alaska-Chukotka plate. The inferred fossil spreading center for the Canada Basin is shown by a double line flanked by magnetic anomalies (positive-thin solid line, negative-thin dashed line) (Laxon and McAdoo, 1994). Abbreviations: AN - Angayucham belt, AR - Alpha Ridge, BR - Brooks Range, CB - Canada Basin, CH - Chukotka, CP - Chukchi Plateau, CR - Chersky Range, GR - Gakkel Ridge, LR - Lomonosov Ridge, MB - Makarov Basin, MR - Mendeleev Ridge, NSI - New Siberian Islands, WHA - Wrangel-Herald Arch, WI - Wrangel Island.

\section{Regional tectonic setting}

The Arctic Ocean consists of two major sub-basins, the younger and relatively well-understood Eurasian Basin and the older and more controversial Amerasian Basin (Fig. 1). Based on magnetic anomalies, the Eurasian Basin began its rift opening in the Paleocene ( $\sim 56 \mathrm{Ma})$ and represents the northern continuation of the mid-Atlantic rift (e.g. Krisstoffersen, 1978; Rowley and Lottes, 1988; Engen et al., 2003; Glebovsky et al., 2000) (Fig. 1). The Lomonosov Ridge is a thin strip of continental crust that separates the Eurasian Basin from the Amerasian Basin (Weber and Sweeney, 1990; Jokat et al.,1992; 1995) (Fig. 1). It restores against the Barents Shelf prior to spreading in the Eurasian Basin (Rowley and Lottes, 1988). The Amerasian Basin consists of several bathymetrically complex basins and highs: the Makarov Basin, the Alpha-Mendeleev Ridge, the Canada Basin, and the Chukchi Borderland (Fig. 1). Based on a set of subparallel to fan-shaped (suggesting about $10^{\circ}$ of rotation) magnetic anomalies in the Canada Basin (Fig. 1), a rotational rift opening for the Amerasian Basin has been proposed and sup- ported by many workers (e.g. Grantz et al., 1979; Rowley and Lottes, 1988; Grantz et al., 1990a, b; Lawver et al., 2002; but see also Gurevich et al., 2006). If the rotational rift interpretation for the origin of the Amerasian Basin is accepted, the Lomonosov Ridge margin must represent a strike-slip or transform plate margin and the Alpha-Mendeleev Ridge must represent a post-rift volcanic edifice, possibly a hot spot track (Forsythe and others, 1986; Lawver et al., 2002). According to this model, the vast Siberian Shelf, which adjoins these oceanic features to the south, is considered part of the Arctic Alaska-Chukotka microplate that rotated into its present position during the rift opening of the Amerasian Basin (e.g. Rowley and Lottes, 1988; Grantz et al., 1990a, b; Lawver et al., 2002). Based on the interpretation of seismic stratigraphic data from Alaska and Canada, the opening of the Amerasian Basin is thought to have taken place in the Hauterivian $(\sim 130 \mathrm{Ma})$ and was over by the Albian $(\sim 112 \mathrm{Ma})$ (Grantz et al., 1990a, b) (but see also Gurevich et al., 2006). Embry and Dixon (1990) argue that the main phase of rifting was Barremian-Aptian (Early Cretaceous, 130-112 Ma, Gradstein et al., 2004) whereas seafloor spreading (drift phase) in the Canada Basin began in the Cenomanian (Late Cretaceous, 100-94 Ma). The South Anyui Suture Zone (SAZ) represents the southern boundary of this microplate; its northern boundary (by definition) is the Siberian Shelf edge (Fig. 1). The rotation model thus predicts that the edge of the Siberian Shelf is a rifted passive margin with a sedimentary cover that is at least Albian or older. Many workers have alternatively suggested that at least the Makarov part of the Amerasian Basin formed by rifting orthogonal to the Lomonosov Ridge (Fig. 1) (see Sekretov, 2001, for a summary of ideas). This interpretation, initially based on the identification of magnetic anomalies (Taylor et al., 1981), is controversial because more recent magnetic data (Glebovsky et al., 2000) do not clearly reveal those anomalies. Workers in favor of the rift origin of the Makarov Basin mostly cite a variety of supporting data that favor formation of this basin at a rather young time, in the Late Cretaceous to Paleocene (e.g. Taylor et al., 1981; Rowley and Lottes, 1988). The hypothesized rifting of the Makarov would have been nearly orthogonal to the Siberian Shelf edge and the age of this rifting would have clear implications for the geology and structuring of acoustic basement rocks and the age of the sedimentary cover of the Siberian Shelf. Basically, the two models discussed above have very different implications for the origin and history of the Siberian Shelf. Although the geology of the New Siberian Islands has been considered in testing models for the rift history of the Amerasian Basin (e.g. Kosko et al., 1990; Kos'ko and Trufavov, 2002, and summary by Sekretov, 2001), neither model has carefully considered the structural history of Arctic Russia in Chukotka.

The Pevek region of the Russian Arctic is located within the Arctic Alaska-Chukotka plate (as described above) and is bordered by the part of the East Siberian Shelf that lies south of the Makarov Basin and the Mendeleev Ridge of the 
Amerasian Basin (Figs. 1, 2, and 3). Its geology, especially its stratigraphy and the progression and timing of structural events, is critical to the interpretation of the limited offshore seismic data from the Siberian Shelf. These data in turn provide important constraints for the timing, origin and history of the part of the controversial Amerasian Basin that lies to the north.

\section{Overview of the geology of the Pevek region}

The dominant map-scale structures developed along the coast of Arctic Russia and southward into Chukotka are folds, penetrative deformation and thrust faults of the Anyui-Chukotka fold belt (Figs. 2 and 3). The fold belt is believed to be the result of the collision of the Chukotka microplate with Eurasia; the South Anyui Zone (SAZ) is the resulting suture zone (Figs. 1, 2, and 3) (e.g. Seslavinsky, 1979; Parfenov, 1984; Bogdanov and Til'man, 1992; Natal'in at al., 1999; Sokolov at al., 2001, 2002, this volume). In the AnyuiChukotka fold belt, Devonian to Triassic stratigraphic units are involved in a series of map-scale folds portrayed both on detailed (1:200 000) geologic maps and on regional scale geologic compilations (e.g. Gorodinsky, 1980) (Figs. 2 and 3). Strata of Jurassic and Cretaceous age are only locally exposed across Chukotka, but are present from the coastline at Pevek southwestward to Bilibino (Gromyko and Khruzov, 1967; Sosunov and Tiliman, 1960; Belik and Susunov, 1969) (Figs. 2, 3, and 5). Jurassic and Cretaceous strata were described as the "Rauchua Basin" (Sosunov and Til'man, 1960; Bogdanov and Til'man, 1992; Parfenov et al., 1993) and categorized as a post-tectonic "overlap" sequence in Nokleberg et al. (1994, 1998). On older geologic maps, these strata are portrayed and described as deposited unconformably over deformed Triassic and Early Jurassic basinal deposits (e.g. Sosunov and Tilman, 1960; Paraketsov and Paraketsova, 1989; see also discussion in Nokleberg et al., 1994). However, the same deposits were termed the "Myrgovaam Basin" by Baranov (1996) and Akimenko (2000) who alternatively describe these strata as detached and in the hanging wall of a thrust plate, and also involved in regional folding and thrusting. This conclusion is compatible with the regional folds in the map pattern of this unit as portrayed on 1: 200000 scale geologic maps (Fig. 3). Additional field studies (Miller et al., 2004, 2006) further support this interpretation. The results from this study help to confirm it - the Jura-Cretaceous units are involved in regional folding and thus help place important constraints on the timing of events in the Arctic.

Cretaceous plutons cut all fold-related structures of the Anyui-Chukotka belt and are associated with abundant dike swarms (Figs. 2, 3, and 4). The age constraints on plutons in the Pevek region are based mostly on K-Ar dating where reported ages range from about $150 \mathrm{Ma}$ to Late Cretaceous (85 Ma) (Gelman, 1995; Dudkinskii et al., 1997; Akinin and Kotlyar, 1997; Tichomirov and Luchitskaya,
2006; V. V. Akinin, personal communication, 2006). Plutons in the Bilibino region (to the southwest) have been dated using the U-Pb method on zircon and show a much narrower range of ages from about 108 to $117 \mathrm{Ma}$ (Miller et al., this volume), ages we consider to be a more reliable range. In the Alarmaut massif north of Bilibino (Fig. 3), in addition to cutting (post-dating) regional fold-related structures, Cretaceous plutons at greater depths in the crust were intruded during vertical flattening and subhorizontal stretching of surrounding rocks at elevated metamorphic conditions (Miller et al., this volume). Thus, all data across a broad region support the interpretation that the intrusion of Cretaceous plutons represents a major change in tectonic regime from compression to extension. Gently dipping volcanic sequences of the Okhotsk-Chukotsk Volcanic Belt (OCVB) overlie all older rocks in Chukotka, including the Cretaceous granitoids, along a profound, regionally developed angular unconformity. The near flat-lying volcanic rocks of the OCVB are traditionally cited as the younger age limit for deformation in the Anyui-Chukotka fold belt and as the upper age bracket for final deformation in the South Anyui Zone. However, field and geochronologic studies have shown that the oldest volcanic rocks of this belt are about $90 \mathrm{Ma}$, mostly younger than previously believed (e.g. Akinin et al., 2009; Tichomirov et al., 2006). Thus the OCVB represents a period of distinctly younger magmatism than that represented by the older $\sim 117-108 \mathrm{Ma}$ age plutons dated in the Bilibino region of Chukotka (Tichomirov et al., 2006; Akinin and Kotlyar, 1997; Katkov et al., 2007). Although the two magmatic belts partially overlap in map pattern (Figs. 2 and 5), the main OCVB post-dates the development of a profound regional unconformity and lies to the south of the Pevek region, representing a southward jump in the locus of magmatism with time. The distribution of OCVB along the strike length of the Pacific margin of Russia has been used to argue that it represents a subduction related volcanic belt (e.g. Parfenov, 1984, 1991; Parfenov et al., 1993; Nokleberg et al., 1994; Zonenshain et al., 1990). Thus by the time it formed, the magmatic "action" had shifted from the Arctic coast of Russia to a position closer to today's Pacific margin. These relationships underscore the importance of studying the ages, compositions and petrologic origins of the older granitoid bodies because it is this group of magmatic rocks, not those of the OCVB, that will be the most useful in providing upper age brackets on the time of collision related deformation and final motion in the SAZ, thus providing additional constraints on Arctic plate reconstructions.

The shaly to slaty, silty and sandy sedimentary and metasedimentary strata of the Pevek Region are not well exposed, covered by wide expanses of tundra (Figs. 4 and 5). Cretaceous granitoid plutons are sub-circular in shape and these more resistant rock types underlie isolated mountains and mountainous parts of the region (Fig. 4). Based on geophysical data, the granitic bodies are thought to connect at depth, representing batholith size intrusions (Dudkinskii 


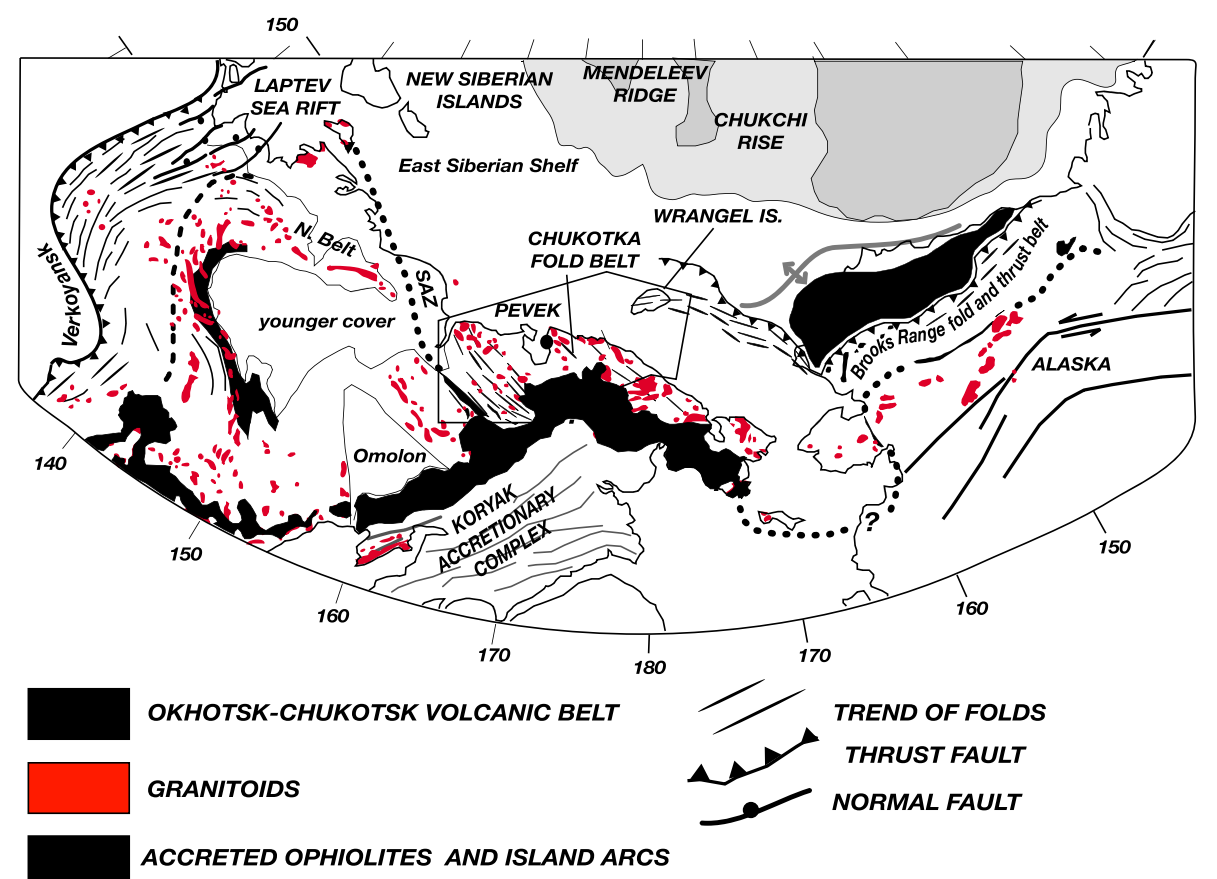

Fig. 2. Regional tectonic setting of Chukotka with respect to adjacent Alaska showing major structural/tectonic features and all of the various magmatic rocks and belts discussed in text. Box outlines the location of Fig. 3. Modified after Miller et al. (2006).

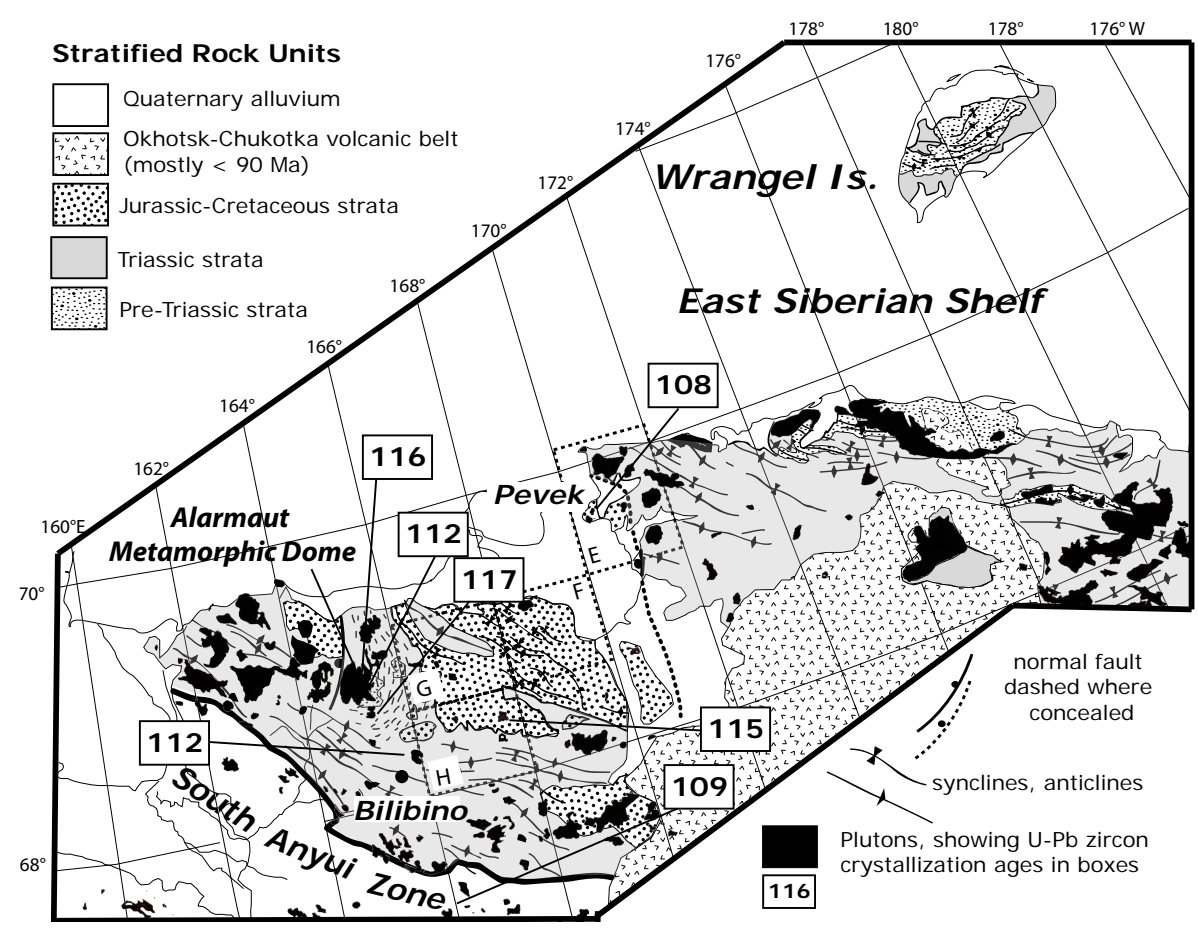

Fig. 3. Generalized geologic and structural map of the broader Pevek region showing regional trends of map-scale fold axes, Cretaceous (?117 to ?108 Ma) post-folding, syn-extension plutons and locally developed ductile extensional fabrics (Alarmaut metamorphic dome) and northern boundary of the South Anuyi Zone (Sokolov et al., 2002). U-Pb crystallization ages for plutons are from Miller et al. (this volume). Dotted square outlines are the boundaries of published 1:200000 scale geologic maps used for Cretaceous dike and quartz vein orientations discussed in this paper, and are labeled E-H corresponding to the compilations shown in Fig. 7. (E) Gromyko and Khruzov (1967), (F) Grigorev and Paraketsov (1962), (G) Belik and Sosunov (1969), (H) Sosunov and Tilliman (1960), Akimenko (2002). Units and structures are compiled from Gorodinsky (1980). 
et al., 1997). More resistant, contact-metamorphosed strata are best exposed along the flanks of these plutons but stratigraphic and sedimentologic details are obscured by hydrothermal alteration and contact (hornfels) metamorphism (Figs. 4 and 5). Fortunately, the mostly non-resistant sedimentary rocks are superbly exposed along sea cliffs and, together with stream and river bank exposures, provide excellent localities for detailed studies, where we focused our attention.

\section{Stratigraphy}

Devonian to Cretaceous strata surrounding Pevek are regionally deformed and variably metamorphosed. The degree of deformation and grade of metamorphism generally increase with stratigraphic age and structural depth in the section, an observation that is generally the case in the Anyui Chukotka foldbelt (e.g. Katkov et al., 2004, 2006; Miller et al., this volume). Because of penetrative deformation and mild metamorphism, fossils, where they occur, are also poorly preserved. Contacts shown as unconformities/disconformities on stratigraphic columns accompanying the 1:200 000 geologic maps of the region (e.g. Fig. 6) (Gromyko and Khruzov, 1967) are somewhat arbitrarily designated and represent a lack of fossils in a given age range rather than hard field evidence for an unconformity such as conglomerates, angular contacts and incision. Folding and penetrative deformation also compromise the thickness estimates shown on these columns (Fig. 6).

The oldest sedimentary rocks in the region are exposed NE of Pevek in the Cape Kiber region (Figs. 3 and 4). Here, Devonian and Carboniferous strata occur in the core of anticlinal structures (Fig. 3). Cape Kiber itself consists of deformed granitoids dated as Devonian by Cecile et al. (1991). The Devonian sequence consists of shallow marine clastic and carbonate rocks (base not exposed) that are unconformably (?) overlain by Carboniferous to Permian calcareous siltstones, shales and minor limestone (700 m) (Fig. 6).

Across Chukotka, the basal contact of the Triassic is mapped as conformable with underlying Permian or disconformable on Carboniferous strata. The lower part of the Triassic is notable in that it contains abundant masses and sills of gabbro/diorite. Conventional K-Ar whole rock ages on the diorites range from 250 to 190 Ma but they have not been dated by more precise methods. (Bychkov and Gorodinsky, 1992; Gelman, 1963; Ivanov and Milov, 1975). In the Pevek region, the Triassic is Carnian and Norian based on fossils (Fig. 6) and does not contain mafic sills and dikes. Except for the upper part of the Norian, which is described as having a greater proportion of sandstone, the Triassic consists mostly of fine-grained slates and siltstones with thin sand beds. They are interpreted as a distal shelf basin or deep water basin turbidite sequences (Tuchkova et al., 2006, this volume). The

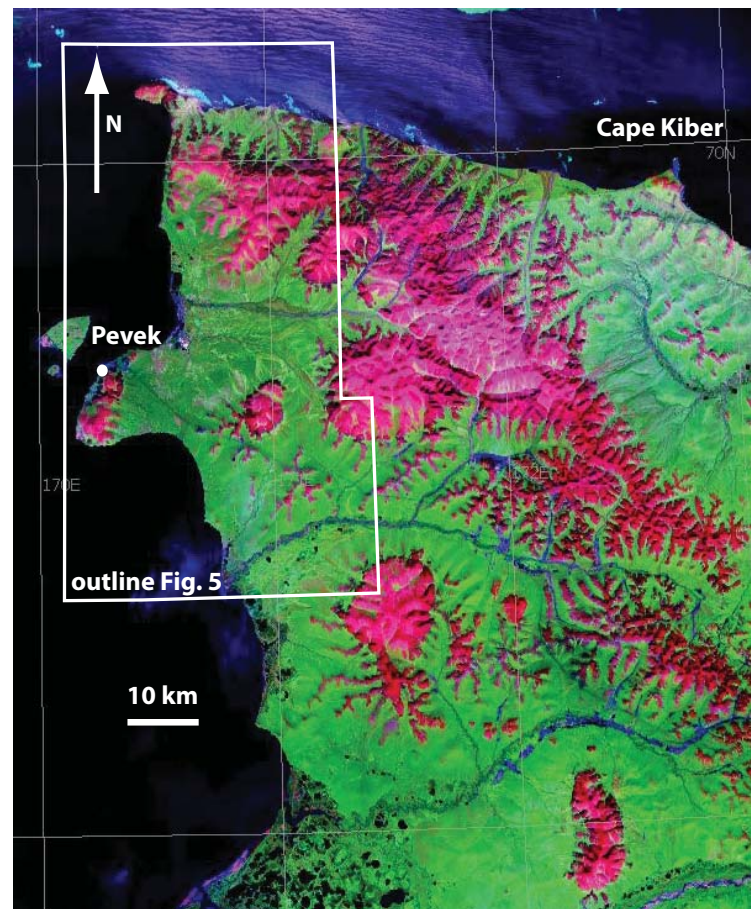

Fig. 4. Landsat 7 image of Pevek region, courtesy of NASA WorldWind geocover imagery, showing near circular outlines (contacts) of Cretaceous plutons (pink), such as the Purkanayansk massif, large regions of quaternary alluvium and cover and very poor exposure of sedimentary and metasedimentary country rocks. Scale shown is approximate.

Triassic is poorly fossiliferous with the exception of a few localities (Fig. 6).

Jurassic fossils are rare in Chukotka and this has been used to suggest that a major depositional break and unconformity might exist between Triassic and Cretaceous strata. Recently, Jurassic microfossils have been reported from rocks previously mapped as Triassic near Pevek (I. Yu. Cherepanova, personal communication, 2006). Thus it is possible that future detailed paleontologic studies or detrital zircon studies providing minimum ages for sandstones might reveal a more complete time-stratigraphic section in this otherwise poorly fossiliferous and penetratively deformed section.

The contact between Cretaceous and Triassic strata is mapped as an (unexposed) fault in the region we studied (Figs. 3 and 5). The fault could be interpreted as a west sidedown normal fault (as portrayed in Fig. 3) but the younger Cretaceous strata could also be preserved as part of a regional synclinorium (Fig. 3). The Pevek region is one of the few places where Cretaceous strata are superbly exposed because of the extent of sea cliff outcrops along the coast. The Cretaceous consists of medium bedded (10's of $\mathrm{cm}$ to up to $1 \mathrm{~m}$ thick) sandstone and siltstone with interbedded shales or slates. Graded beds, abundant bottom markings (load casts, grooves and tool marks) suggest that the bulk of 


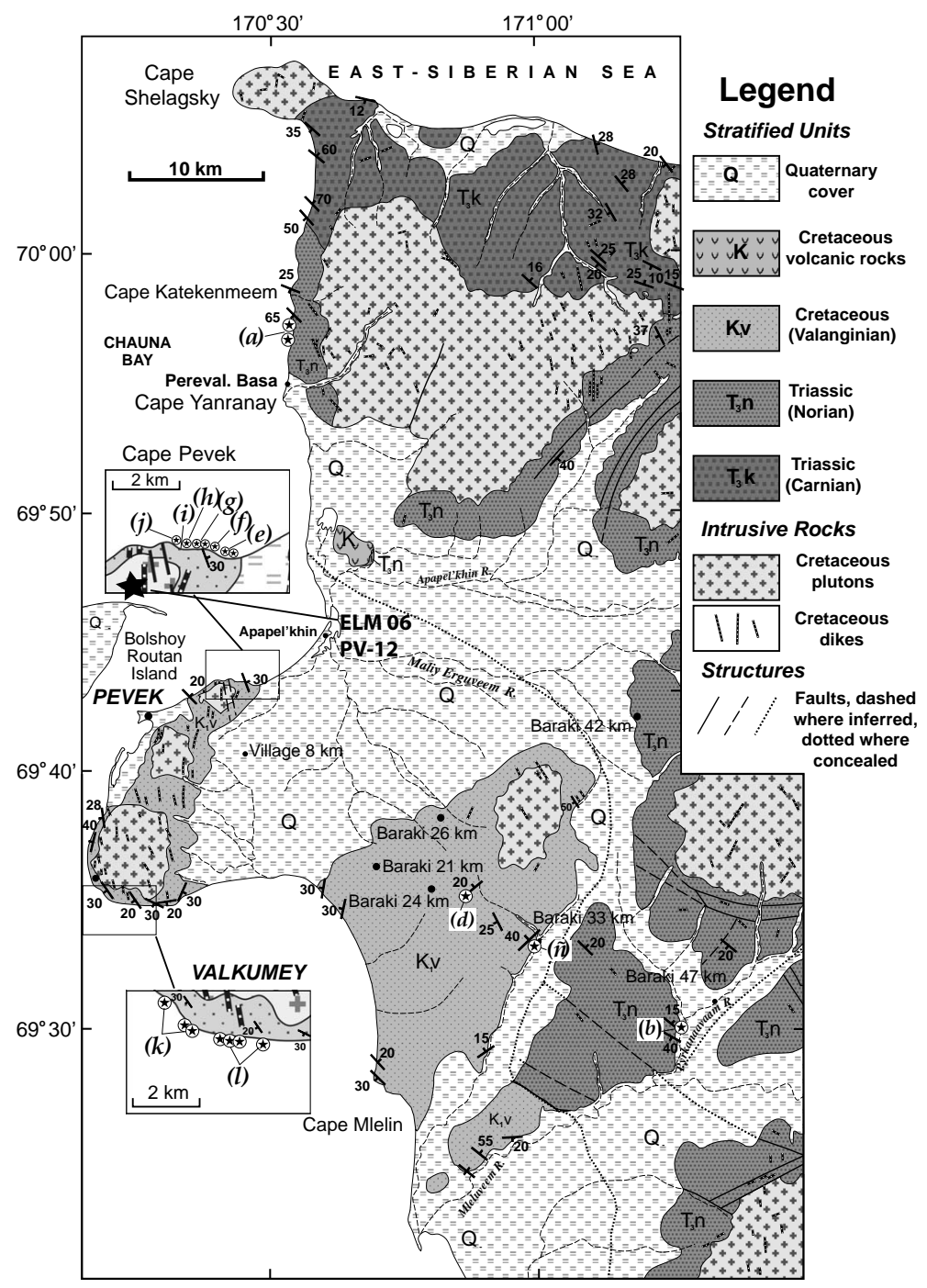

Fig. 5. Detailed geologic map of the Pevek region, simplified after Gromyko and Khruzov (1967) showing exact locations (and names) of our detailed study areas (stars and letters) and location of U-Pb zircon sample locality ELM06 PV 12 (black star in inset diagram). Note that the lower metamorphic grade Jura-Cretaceous age sediments (Cretaceous, Valanginian) are only mapped in contact with the Triassic as a fault in only only one poorly exposed locality; the rest of the contact is obscured by Quaternary cover.

these sediments are gravity flow deposits into a shelf basin or deeper water basin setting. Petrographically, sandstones are immature and grains are angular and unsorted, consisting of abundant feldspar, micas and lithic fragments of metasedimentary and volcanic rocks, in addition to quartz. The Cretaceous is poorly fossiliferous (Fig. 6) with Aucella sp. indeterminate (Late Jurassic-Early Cretaceous) and plant fossils Cladophlebis sp. indeterminate (Early Cretaceous) reported from the Pevek area. A greater number of species of $A u$ cella (Buchia) have been identified at various sites in the 1:200 000 quadrangles to the SW of Pevek and have been assigned to the Valanginian (e.g. Belik and Susunov, 1969). Based on similarities in deformational history and style of deformation (see below) together with the lack of clear-cut evidence for an unconformity it is possible that Cretaceous strata in the Pevek region could have been deposited in sequence with older strata. However, this question cannot be addressed definitively near Pevek, because the base of the Cretaceous is not exposed. The greater degree of penetrative deformation observed in the Triassic versus the Cretaceous could alternatively be used as argument for an unconformity.

\section{Structural geology of the Pevek region}

Our ability to compile regional structural data for the Pevek region was hampered by the general poor exposure of the units and by the fact that detailed structural observations could only be made locally, at widely separated sea cliff 


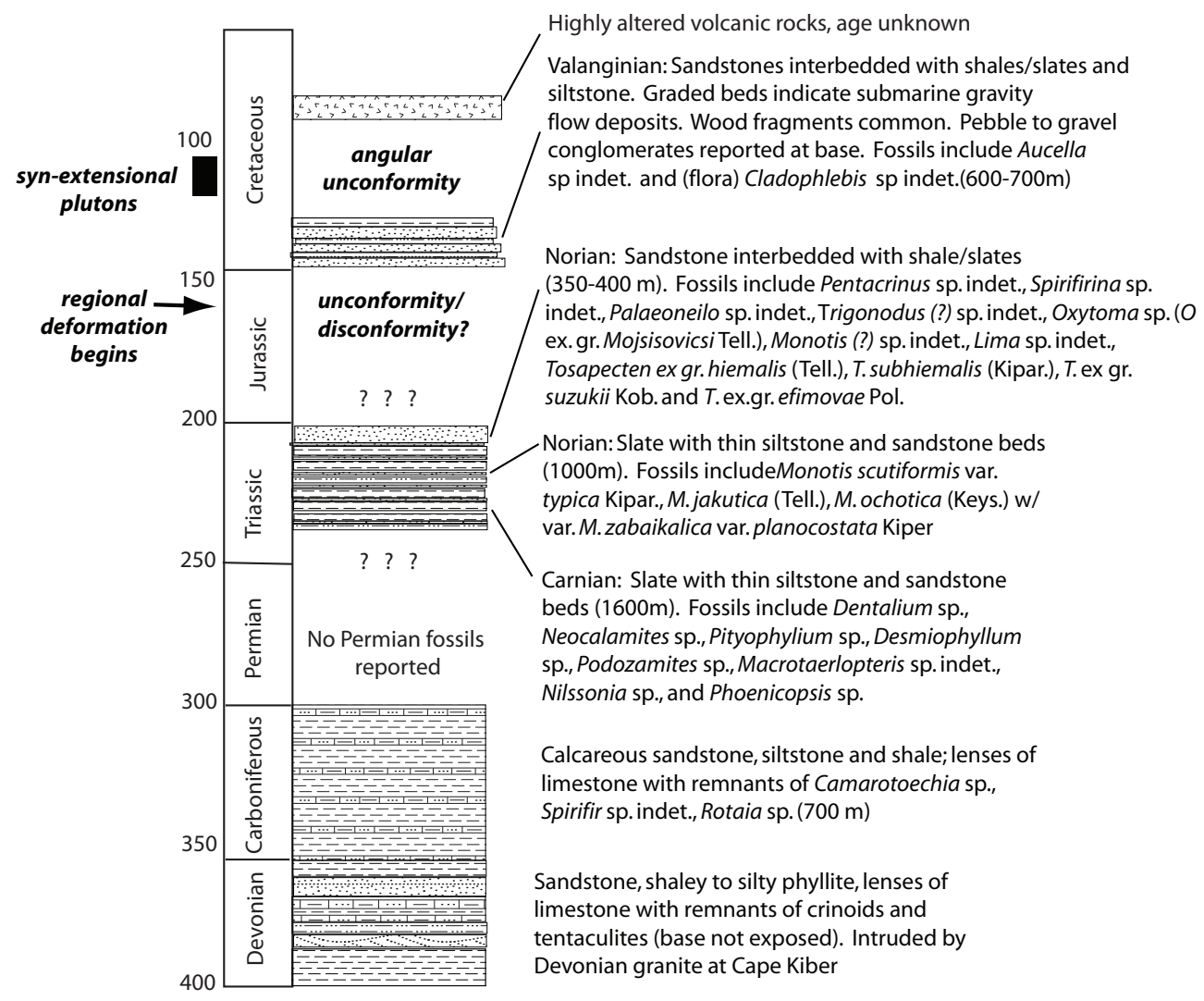

Fig. 6. Generalized stratigraphic column of the Pevek region after Gromyko and Khruzov (1967) and Belik and Susonov (1967). Note that thickness of units and exact stratigraphic succession as shown on legends and columns of geologic maps are possibly compromised by tight folding and internal deformation of units.

exposures. Younger doming (cross-folding) related to pluton intrusion is evident across the region based on landsat data (Fig. 4). The observation of numerous small-scale brittle faults in outcrop suggests that map-scale faults (a few shown on geologic map) could have rotated earlier-formed structures and fabrics in indeterminate ways. Despite these reservations and possible complexities, the data we collected are fairly coherent and the progression of events is the same in all outcrops studied.

\subsection{Regionally developed penetrative deformation: an overview}

Both Triassic and Cretaceous strata studied are folded at the outcrop and the map scale and possess a variably developed cleavage, which is much more strongly developed and represents higher strain in Triassic rocks than in Cretaceous strata. This may be related to the fact that stratigraphically older strata have generally experienced higher strains and are more deformed than younger strata in the Anyui Chukotka foldbelt (e.g. Katkov et al., 2006), a fairly common relationship in the deeper levels of fold and thrust belts (e.g. Ramsay and Huber, 1983), but more than one deformation in the older rocks can- not be entirely ruled out without further work. Where folds are observed in outcrop, cleavage is axial planar to folds. We interpret this penetrative fabric as regional in nature, related to shortening by folding, accompanied by low-grade metamorphism increasing with structural depth. The summary below lists the overall generalities of our structural data set, followed by details of the data collected at individual locations. Plutons, dikes, quartz veins and brittle faults cut this regional deformational fabric and are discussed in a following section.

For a regional overview of the folding event, we compiled bedding readings across the area of Fig. 5, based on 1:200 000 scale geologic mapping (Gromyko and Khruzov, 1967). Poles to bedding $(n=42)$ form a diffuse great circle that defines a sub horizontal N40W trending fold axis consistent with the orientation of mapped folds (Figs. 3 and 7a). Together, all of our measured bedding attitudes at disparate sea cliff and stream locations in both Triassic and Cretaceous strata show a bit more scatter (Fig. 7b) yet poles to bedding also form a diffuse great circle girdle that defines a similar fold axis (N35W, sub horizontal) (Fig.7b). Individual areas have better defined structures but their orientation varies somewhat between localities. 

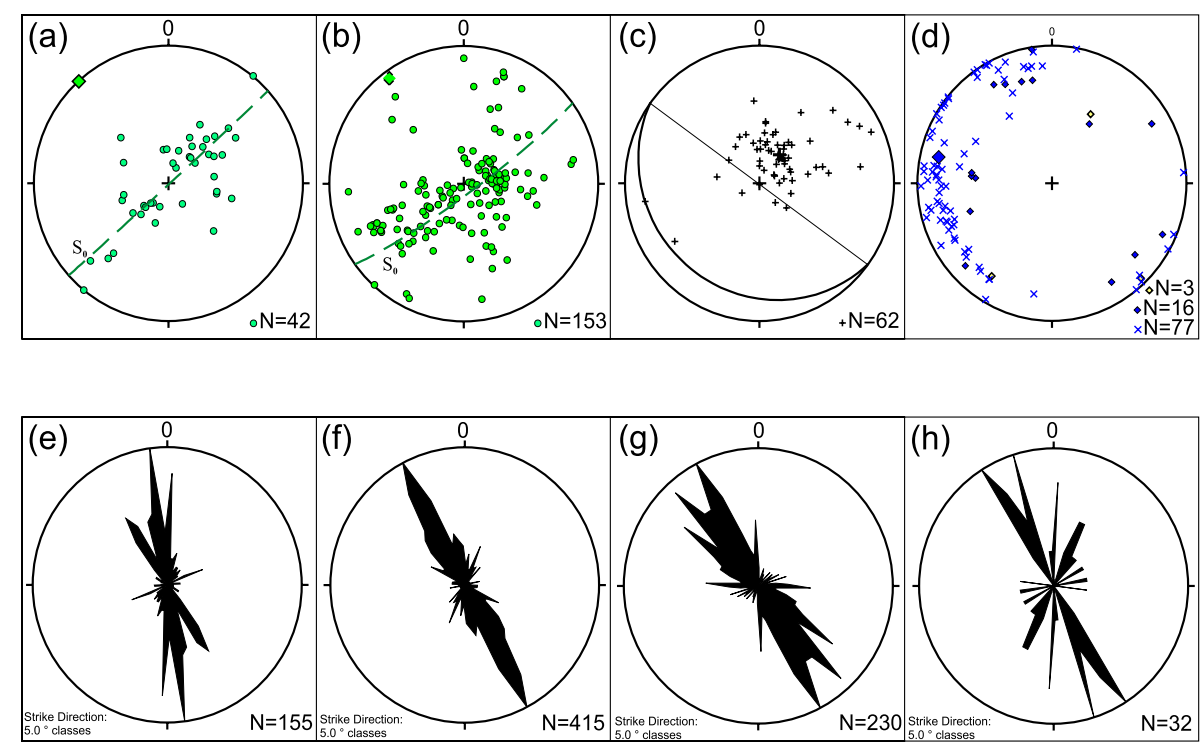

Fig. 7. Compiled structural data and dike orientations for the Pevek and surrounding region. All stereonet diagrams are equal area, lower hemisphere projections. The number of data points $(\mathrm{N})$ is indicated in lower right of diagrams. (a) Poles to bedding measurements taken from geologic map of the Pevek region (dots) and the regional fold axis they define (square). (b) Poles to bedding (this study) (circles), average girdle or great circle defined, and the pole to this plane (square). (c) All poles to measured S1 cleavage showing the weighted mean of this distribution (black dot) and the average orientation of S1 thus defined (great circle). (d) Bedding-cleavage intersection lineations (L0x1) (shown as X's) and measured fold axes (shown as black diamonds) and bedding-fault cut off lines (open diamonds). (e-h) Strike orientation of dikes as measured off the geologic map of Pevek region (Fig. 5) (e) and the three 1:200000 quadrangle maps highlighted to the SW of Pevek (locations shown on Fig. 3). (f) Grigorev and Paraketsov (1962), (g) Belik and Sosunov (1969), (h) Sosunov and Tilliman (1960), Akimenko (2002).

The penetrative cleavage is preferentially developed in shales (now slates) and only weakly developed to nonexistent in interbedded sandstones (Fig. 8a). Poles to measured cleavage, combined from all locations, form a diffuse cluster and its weighted mean center yields an average cleavage plane oriented N55W/20SW (Fig. 7c). Bedding-cleavage intersection lineations and directly measured fold axes are widely distributed, trending in all directions from N-S to E$\mathrm{W}$ and plunging gently to the west (Fig. 7d). Such a wide variation in the orientation of bedding-cleavage intersection lineations is unusual, especially in rocks that are relatively low strain and exhibit evidence for only one main folding event. The reason for this variation is not clear but could result from vertical axis rotation of some of our localities with gently-dipping beds (these rotations would not be obvious in the general bedding or cleavage data (Fig. 7) and or local submarine slumping during deposition leading to beds of variable orientation before deformation. Because the orientation of cleavage is fairly constant (Fig. 7c), it is unlikely that significant post-deformational tilting by brittle faulting or refolding could produce the observed distribution.

\subsection{Regionally developed penetrative deformation: local details}

\subsubsection{Yanranay (Triassic)}

The beach cliffs north of the town of Yanranay, $\mathrm{N}$ of Pevek (Fig. 5) provide excellent exposure of Triassic strata. Here, bedding is tightly folded and strongly cleaved. Strain is substantially higher than in Cretaceous strata (Fig. 8b). Poles to bedding define a fold axis that is W-NW trending, plunging shallowly to the W (Fig. 8a). The fold axis defined by bedding measurements is parallel to measured bedding-cleavage intersection lineations. Axial planes of measured folds are steep and W-NW striking (Fig. 9a). Folds are vergent to the northeast.

\subsubsection{Baraki 47 (Triassic)}

This is the only location (Fig. 5) where two generations of folds were visible at the outcrop scale. The younger folds fold both bedding and S1 cleavage described above. The older cleavage is at low angles or sub-parallel to bedding. In Fig. 9b, bedding and S1 cleavage are not distinguished (because they are sub-parallel) and their poles are distributed in a great circle that defines the second-generation fold axis that trends WNW and is sub-horizontal (Fig. 9b). Spaced 

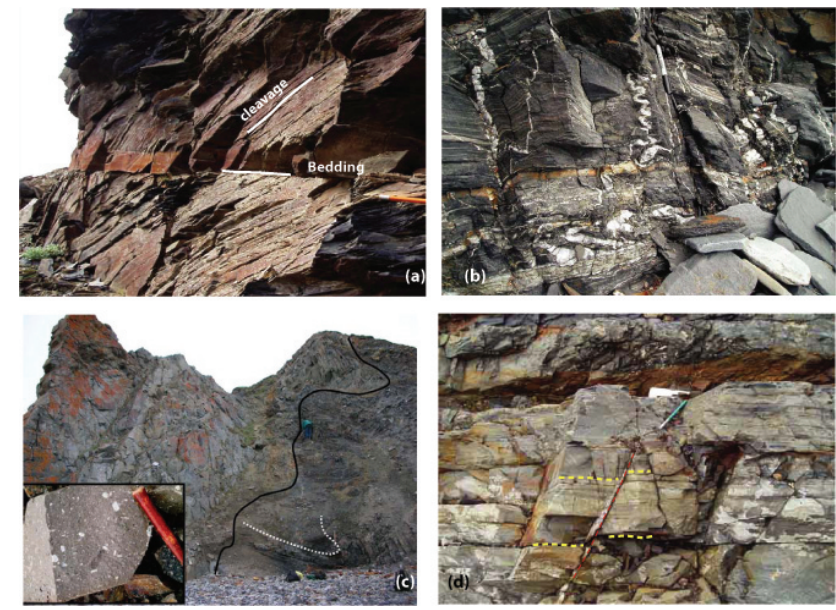

Fig. 8. (a) Late Jurassic-Early Cretaceous sandstones and siltstones at locality Baraki 33 (Fig. 4), showing bedding (So)-cleavage (S1) relations. Looking west, cleavage dips to south. (b) Late Triassic (Norian) siliceous siltstones and fine sandstones with a welldeveloped cleavage. An early quartz vein is folded, yielding an approximate estimate of the strain represented by the cleavage. Locality: north of Cape Yanranay (Fig. 5), looking east. (c) Photo of porphyritic dike cutting across folded beds and cleavage; inset shows close-up of dike rock. Dike trends nearly N-S, view is towards NW, locality Cape Pevek (Fig. 5). (d) Photo of small offset normal fault, view looking approximately N. Locality Cape Pevek (Fig. 5).

axial plane foliation of the second set of folds (poles shown as crosses in Fig. 9b) dip N-NE about 35 degrees. Measured second-generation fold axes (black diamonds) are W-NW trending, sub-horizontal, and parallel to the fold axis defined by bedding and the earlier cleavage. We interpret these data to represent co-axial refolding of bedding and earlier formed cleavage during a progressive deformational event; however, small scale folds measured in this locality are south-vergent, not north-vergent like most of the structures measured elsewhere and could be related to conjugate back thrusts.

\subsubsection{Baraki 33 (Cretaceous-Valanginian?)}

River bluff exposures of strata mapped as Cretaceous at this locality (Fig. 5) are little metamorphosed and original sedimentary structures are well preserved. Fossil plant fragments (wood) were seen, but no macro fauna. Cleavage is present at an angle to bedding and is developed only in shales, not in sandstone beds (Fig. 8a). Bedding dips gently north here (Fig. 9c). The dip of cleavage varies as a function of lithology. Dips are closer to those of bedding at bases and tops of shale units due to differential strain (Fig. 8a) and indicate a south over north sense of shear. The great circle described by poles to cleavage is related to strain variation and the obtained fold axis trends NW and is sub-horizontal, parallel to measured bedding-cleavage intersection lineations or L0x1 (Fig. 9c). Quartz veins, unrelated to folding, indicate N-NNE extension direction (Fig. 9c).

\subsubsection{Baraki 24 (Cretaceous-Valanginian?)}

In quarry exposures along the main road east to Igvekinot (Fig. 5), bedding dips gently NW and cleavage dips gently south (Fig. 9d). Intersection lineations trend almost E-W. Two sets of quartz veins occur. The older (open triangles, Fig. 9d) quartz veins trend N-S to NE and cut sandy beds but not inter-bedded shales. They are likely related to deformation within the beds (stretching) during folding. If so, they would indicate approximate fold-axis parallel stretching. The younger quartz veins trend $\mathrm{NW}$ and indicate NESW oriented extension during their formation (Fig. 9d).

\subsubsection{Eastern Cape Pevek (Cretaceous-Valanginian?)}

Poles to bedding define a diffuse girdle whose pole represents a fold axis that trends NW and is sub-horizontal, parallel to measured bedding-cleavage intersection lineations (Fig. 9e). Average cleavage dips moderately to the SW.

\subsubsection{Central Cape Pevek (Cretaceous-Valanginian?)}

Poles to bedding define a fold axis that trends NNW and plunges slightly NW, parallel to directly measured fold axes (Fig. 9f). Axial planes of these outcrop-scale folds dip W-SW (Fig. 9f). Detailed measurement of two outcrop-scale duplex structures are shown in Figure $8 \mathrm{H}$. In these structures, bedding defines a fold axis that trends NW and is sub-horizontal. The bedding-fault cutoff line (open diamond) as well as fold axis (black diamond) are sub-parallel to the fold axis defined by bedding measurements. One of the small-scale thrust faults is southwest-vergent, another is west-vergent with oblique reverse slip. A third small-scale thrust fault cuts folded beds that describe a N-S trending fold axis, and is also west-vergent (Fig. 9i). Bedding-fault cut-offs are also parallel to measured fold axes. These last two examples of measured structures and their orientation are a good example of where the data are consistent in a given place, but fold axes are NS trending rather than NW trending or EW trending.

\subsubsection{Western Cape Pevek (Cretaceous-Valanginian?)}

Bedding here dips gently, about $25^{\circ}$ to the NW (Fig. 9j). Two cleavage measurements indicate cleavage is dipping southwest and a third indicates it dips NNW. Bedding-cleavage intersection lineations are subhorizontal or plunge gently to the NNW. Extensional, quartz-filled fractures trend NNE, dip steeply, and are perpendicular to measured fold axes suggesting extension parallel to the trend of fold axes. 


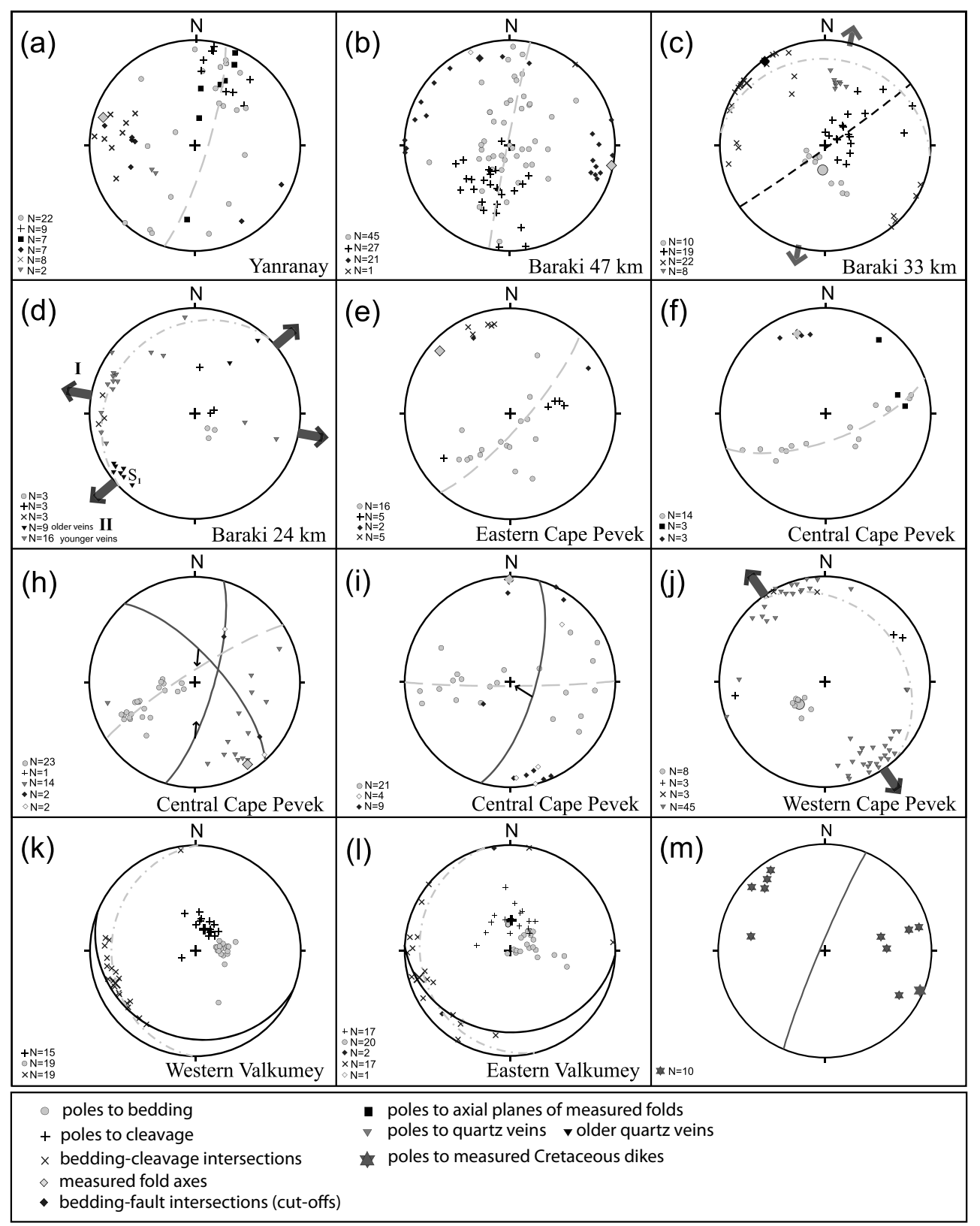

Fig. 9. Equal area, lower hemisphere projection of structural data from specific localities in the Pevek Region. Letters of plots correspond to localities shown on map in Fig. 5. Numbers of all types of data points $(\mathrm{N}=)$ are listed in lower left of each plot. In all diagrams, green circles are poles to bedding, crosses are poles to cleavage or S1, blue x's are intersections between bedding and cleavage or L0x1, black diamonds are measured fold axes, blue diamonds are small thrust-fault cutoff lines (intersection between two sets of beds cut by thrust fault), squares are poles to axial planes of measured folds and yellow triangles are poles to quartz veins. Diagram (m) shows poles (red stars) to all directly measured Cretaceous dikes. Directions of shortening are shown as inward-directed black arrows; directions of extension by outward-directed grey arrows on outside of stereonet. Where indicated, great circle fits to poles to bedding and cleavage are shown by heavy dashed green lines and their poles are bigger diamonds, thin dashed green great circles are average bedding orientations, black great circles are average cleavage orientation. Red lines are thrust fault planes.

\subsubsection{Western Valkumey (Cretaceous-Valanginian?)}

Poles to bedding show uniformly gentle dips to the W-SW (Fig. 9k). Poles to cleavage show uniform gentle dips to the SW. Intersection lineations show a surprising scatter, dis- cussed in the introduction of the structural data section. This scatter is seen in our collective data from the region and some of the possible ways of explaining it were discussed in the introduction to this section. 


\subsubsection{Eastern Valkumey (Cretaceous-Valanginian?)}

Bedding dips uniformly gently to the west (Fig. 91). Cleavage dips gently to the south. The average intersection of the two yields an E-NE trending intersection which is askew to the general more NW trending regional folding. The measured intersection lineations between bedding and cleavage ( $\mathrm{S} 0 \mathrm{x} 1$ ) again show a great deal of scatter from NW to SW trending (Fig. 91). Given the rather systematic orientation of cleavage, this could be due to vertical axis rotation of gently dipping bedding and cleavage and/or tilted or slump-folded bedding prior to deformation.

\subsection{Structural relationships of dikes and plutons}

Plutons and associated dikes sharply cut penetrative deformational fabrics and folds in Mesozoic strata (Fig. 8c). Andalusite \pm chloritoid are locally developed in their contact aureoles, suggesting that most of the granitoids were intruded into fairly shallow levels ( $\sim 5 \mathrm{~km}$ depths?) of the crust. Adjacent to plutons, abundant evidence for hydrothermal alteration is seen including quartz veins and extensive bleaching of originally more porous quartzites and siltstones compared to the darker slates and shales. Most plutons are porphyritic with large tabular K-feldspar phenocrysts, which are conspicuous in the finer grained border phases and in the dikes that emanate from the plutons (Fig. 8c). Biotite and hornblende are the most common mafic minerals. On the 1:200 000 geologic map of the Pevek area, the age of these plutons is cited as Late Cretaceous (younger than 99Ma) and they are described as having a compositional range that encompasses granite, quartz monzonite and granodiorite. The dikes are described as Early and Late Cretaceous in age with a compositional range that includes granite (rhyolite), granodiorite (dacite), quartz diorite, syenite and lamprophyre. Using geochemistry, petrology and available K-Ar data, Dudkinskii et al. (1997) divide the granitoids into an early (144 Ma) more mafic suite of monzonite-monzodioritegranodiorite-granite, an intermediate (126 Ma) group of silicic granite-leucogranite magmas and a late (97-85 Ma) suite of leucogranites. Despite the broad age range reported, they believe these magmas form part of a single, possibly initially subduction-related magmatic event, where melts interacted with continental crust in a progressively more significant fashion with time (Dudkinskii et al., 1997). They conclude that the majority of magmas from mafic to felsic can be explained by the interaction of mafic magmas, specifically potassium-rich basalts, with the crust, supplying heat and causing partial melting, leading to the more evolved granitoids in the region (Dudkinskii et al. 1997). A $\mathrm{U}-\mathrm{Pb}$ age utilizing the USGS-Stanford University SHRIMPRG on zircons from one of the Pevek plutons (Sample ELM06 PV-12, location shown on Fig. 5) yields a weighted mean age of 108.1 $\pm 1.1 \quad(\mathrm{MSWD}=4.0, \quad \mathrm{~N}=8$ ) (Supple- ment, see: http://www.stephan-mueller-spec-publ-ser.net/4/ 223/2009/smsps-4-223-2009-supplement.zip). The pluton dated likely connects with the two small plutons mapped to the south of Pevek, forming a larger body at depth (Fig. 5). These three plutons are associated with numerous dikes of similar composition (Fig. 8c). The dated granite forms part of Dudkinskii et al.'s (1997) intermediate age (126 Ma) group of silicic granites. The zircons dated indicate the entrainment of zircons with slightly older ages (115 and 116 Ma) (see Supplement), supporting a somewhat prolonged magmatic event as postulated by Dudkinskii et al. (1997), but the inferred age of magmatism is still considerably shorter and younger than the range of legacy $\mathrm{K}-\mathrm{Ar}$ dates they report.

Direct measurement of ten dike orientations in sea cliff exposures indicate an average steeply dipping plane striking NNE (Fig. 9m). Combined trends of all dikes (these include dikes and map-scale or mappable quartz veins) in the area of Fig. 5, measured from the 1:200 000 geologic map of the Pevek region, are plotted together and indicate an average strike direction slightly west of north (Fig. 7e), suggesting E-W extension during the intrusion of the dikes and associated granitoid plutons. To see if this was representative of a more regional trend, we compiled the orientations of dikes and map-scale hydrothermal quartz veins from the entire region south and west of Pevek to the town of Bilibino (Figs. 3 and $7 \mathrm{f}, \mathrm{g}$ and $\mathrm{h}$ ). These represent a considerable number of measurements and clearly show that dike orientations are remarkably consistent over a broad region and trend NNW, indicating ENE-WSW directed extension during intrusion of Cretaceous granitoids.

\subsection{Brittle structures}

Small offset faults, slickensided fault surfaces and quartz veins were measured whenever encountered. These structures do not represent a significant amount of strain (e.g. Fig. 8d), but if systematic, they can provide useful information on the orientation of strain axes during their formation and clues to the nature of larger-scale structures. In several outcrops we observed small-scale faults cutting parts of the dikes described above and also cutting hydrothermally altered and contact metamorphosed sedimentary rocks. They are often associated with quartz veins and mineralization. It seems reasonable to conclude that they may be broadly contemporaneous with magmatism (or slightly post-date it) which could have provided the hydrothermal circulation systems for the mineralization and quartz veining.

The fault measurements yield fairly consistent data (Fig. 10). Most of the small offset faults trend approximately $\mathrm{N}-\mathrm{S}$ and dip to the east and west, with dip-slip movement histories. These faults appear to define a conjugate set of normal faults (Fig. 10a-n). There also appears to be a lesser set of steep south-dipping faults that show dip-slip to oblique slip motion (e.g. Fig. 101). 
Combining all of the fault data together and utilizing the fault kinematic program (http://www.geo.cornell. edu/geology/faculty/RWA/programs.html) (Marrett and Allmendinger, 1990) we calculated P (shortening) and T (extension) axes for each of the sets of fault planes and striae measured (Fig. 11). This analysis yields an average shortening axis that is sub vertical and a dominant, approximately E-W extension axis (Fig. 11). A lesser SSW-NNE extension axis is also evident (Fig. 11). Together with the data on dike orientations, these data provide robust documentation of the direction of regional extension at the time of Cretaceous magmatism.

\section{Regional correlation and timing of events}

Folding related to crustal shortening is widespread on the Russian mainland in Chukotka and continues northward to Wrangel Island (Kos'ko et al., 1993) and westward to the Siberian Islands (Kos'ko and Trufanov, 2002) (Figs. 2 and 3). Folds in Chukotka are tight with south-dipping to vertical, penetrative axial plane cleavage (Katkov et al., 2004, 2006; Miller et al., this volume). Shallowly dipping, beddingparallel faults or far-traveled "nappes", typical of thrust belts are not generally characteristic of the Chukotka fold belt (Fig. 3). The attitude of fold axes and axial plane cleavage indicate N-S to NE-SW directed shortening (Fig. 3 and data presented here). The onset of deformation is dated by the deposition of syn-orogenic clastic rocks in latest JurassicEarly Cretaceous time - the Rauchua or Myrgovaam Basin (Fig. 3). These sediments record the arrival of clastic material shed from Precambrian basement uplifts and Late Jurassic magmatic sources to the south of Chukotka (Bondarenko et al., 2003; Miller et al., 2008; Soloviev et al., 2006). These syn-orogenic deposits were in turn involved in folding and were shortened together with underlying strata, based on the shared similarity of their main structures (Fig. 3 and data presented here). The youngest fossils reported from sedimentary rocks involved in folding are Valanginian (Belik and Susunov, 1969), which corresponds to the approximate time interval $140.2 \pm 3.0 \mathrm{Ma}$ to $136.4 \pm 2.0$ (Gradstein et al., 2004). Thus deformation began in the Late Jurassic (earliest fossildated syn-orogenic deposits) and continued at least through the Valanginian (youngest strata deformed).

The upper bracket for regional folding-related deformation are the Cretaceous plutons and dikes discussed above. However, the large range in their reported K-Ar ages is confusing. The pluton we dated in Pevek as $108 \mathrm{Ma}$ (see Supplement) provides a clear younger age limit for deformation. Based on ages from a broader region, however (Fig. 3), it is likely that the oldest cross-cutting plutons are at least $117 \mathrm{Ma}$ old. A long-lived ( $\sim 20 \mathrm{Ma}$ ?) period of uplift and erosion postdated this magmatic event and resulted in the regional unconformity beneath the base of the younger OCVB volcanic belt (Fig. 3).

\section{Implications for the geology of the Siberian Shelf}

Based on the above data from the Arctic coast of Chukotka and its comparison to the broader region we have studied, it is clear that several major events of regional significance affected the crustal makeup of this part of Arctic Russia and thus must have also affected the acoustic basement rocks of the offshore Siberian Shelf. As such, these on-land geological relations provide powerful constraints on various possible interpretations of the extremely limited existing offshore data (Fig. 12).

Several authors have summarized and re-interpreted geophysical data for the Siberian Shelf. Both Franke et al. (2004) and Mazarovich and Sokolov (2003) have suggested that, contrary to previous beliefs, a large portion of the Siberian Shelf between the New Siberian Islands and Wrangel lacks well-defined deep sedimentary sub-basins (Fig. 12). Overall, the shelf is characterized by a fairly thin sedimentary cover $(2-3 \mathrm{~km})$ that thickens to at least $7-8 \mathrm{~km}$ near the shelf edge, eastward and northward of the Siberian Islands (e.g. Sekretov, 2001; Franke et al., 2004). These data and interpretations emphasize that the large E-W trending shelf basins described in previous summaries by Fujita and Newberry (1982), Savostin et al. (1984) Fujita and Cook (1990), Parfenov et al. (1993) do not exist (Fig. 12). In addition, the more recent interpretations of offshore data suggest that the series of extensional rift basins mapped on the Laptev Sea Shelf, related to spreading in the Eurasian Basin, do not extend significantly east of the New Siberian Islands (Fig. 12) (but see discussion of the East Siberia depo-center by Franke et al., 2004). As described by Franke et al. (2004), acoustic basement beneath the Siberian Shelf can be clearly mapped even when sediment cover is thickest. No coherent reflectors are seen in the basement rocks in any of the data and the basal unconformity for overlying sediments is mainly smooth to flat, suggesting it was the result of pene-planation prior to final subsidence and accumulation of its sedimentary cover (Franke et al., 2004). The age of this regional erosional surface is critical to interpretation of the age of overlying sedimentary rocks, which in turn is critical to understanding the age of rifting in the Amerasian Basin. Franke et al. (2004) discuss the evidence for the age of this surface in some detail and conclude (in agreement with our new data) that it must post-date granitoid magmatism in Chukotka and the Verkoyansk belt (Fig. 2). However, they state that the age of cessation of magmatism is $70 \mathrm{Ma}$, and thus the age of the seismically mapped unconformity is younger than $70 \mathrm{Ma}$, and that the overlying sedimentary package is Paleocene and younger. However, there is little evidence for plutons as young as $70 \mathrm{Ma}$ in Chukotka and the Verkoyansk. Kos'ko and Trufavov (2002) review geologic evidence from the New Siberian Islands and propose that the unconformity is as old as Aptian-Albian (125 to $100 \mathrm{Ma}$ ). Based on our study and the analysis of the regional geology of the Pevek and surrounding region, we would agree with Kos'ko and 


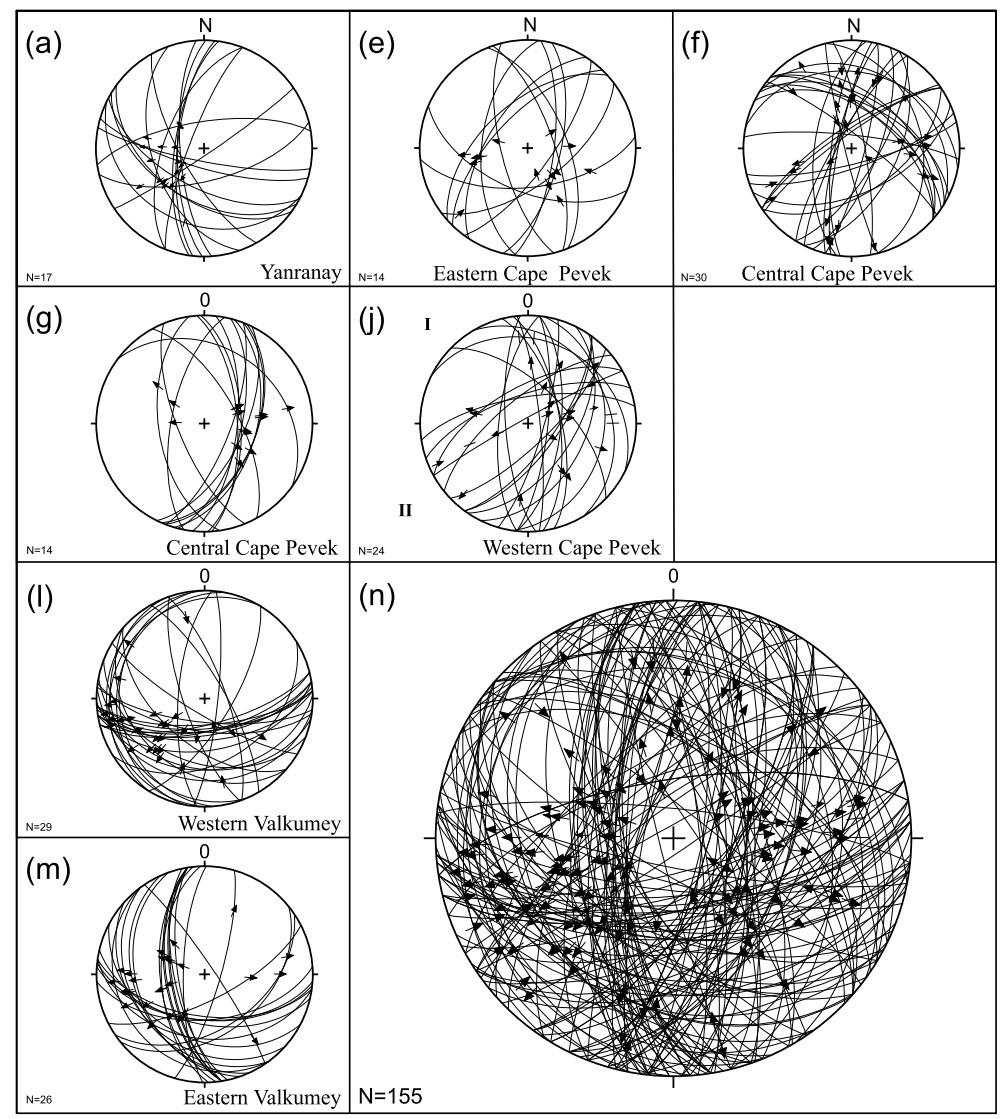

Fig. 10. Equal area, lower hemisphere plots of small offset fault planes and striations (slickensides). Number of measurements shown in lower left $(\mathrm{N}=)$. Arrows on fault planes indicate sense of motion of hanging wall (upper plate) relative to footwall (lower plate). (a)-(m) are data from individual localities as labeled in Fig. 5. The last diagram (n) is the combined data set.

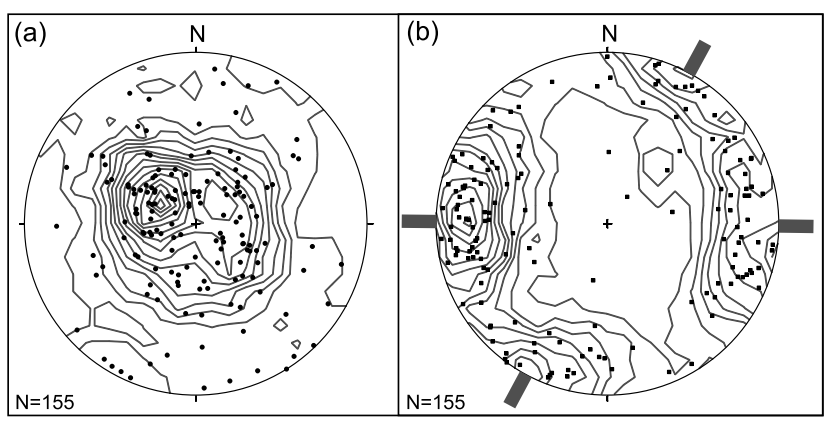

Fig. 11. Fault kinematic solutions. A. Equal area, lower hemisphere plots of $\mathrm{P}$ (shortening) axes (black dots) and B. T (extension) axes (black squares) calculated from fault data shown in Fig. 9, using Fault Kinematics Program (http://www.geo.cornell.edu/geology/ faculty/RWA/programs.html) (Marrett and Allmendinger, 1990), contoured by the Kamb method with $1 \%$ contour intervals shown. Dominant extension directions are shown by grey arrows on outer periphery pf plot (b); shortening direction is sub-vertical in (a). Note that the Fault Kinematics Program utilizes a zero value for the coefficient of friction; $P$ axes would be near vertical if faults initially formed $30^{\circ}$ from shortening axis.
Trufanov (2002) that this unconformity must be considerably older than the base of the Tertiary as proposed by Franke et al. (2004). The erosional surface would have developed at the cessation of plutonism (youngest dated pluton is $108 \mathrm{Ma}$ ) and prior to inception of volcanism in the OCVB at $90 \mathrm{Ma}$ or less, when magmatism steps south of this part of the Arctic coast of Russia. Thus, sediments above this unconformity beneath the Siberian Shelf could be as old as early Late Cretaceous (Albian, $\sim 100 \mathrm{Ma}$ ) rather than Paleocene (younger than $65 \mathrm{Ma}$ ) as suggested by Franke et al. (2004) (the age of their ESS1-ESS2 seismic stratigraphic interval).

Seismic data are virtually non-existent east of the East Siberia depocenter and west of Wrangel Island (Fig. 12). Satellite gravity data (Laxon and McAdoo, 1994) provide little evidence for additional deep sedimentary basins on the shelf north of the Pevek region of Arctic Russia (Fig. 12) (see also Mazarovich and Sokolov, 2003). Notable exceptions include the North Chukchi Sea Basin and the Hope Basin (Fig. 12) (Thurston and Theiss, 1987; Tolson, 1987). The Hope Basin is often shown as connected to the South Chukchi Basin, developed between Wrangel Island and Pevek (Fig. 12). However, based on limited seismic data 
together with gravity data, the South Chukchi Basin appears to be a distinct basin separated from the Hope Basin by a structural high (Fig. 12). The Hope Basin is believed to have formed in the earliest Tertiary (Paleocene) (Tolson, 1987). Based on its similar trend and close location, the South Chukchi Basin could possibly have formed at about the same time. If so, faults that bound this basin would cut the regional unconformity mapped as ESS1 by Franke et al. (2004) and again, would suggest that the sedimentary cover of the Siberian Shelf is likely significantly older than Paleocene. The age of formation and sedimentary fill of the North Chukchi Basin is not known and because it lies to the north of the Mesozoic deformational front referred to as the Wrangel-Herald Arch (Figs. 2 and 12), it could be significantly older and include Paleozoic as well as Mesozoic strata as does the Hannah Trough of offshore Alaska, which occupies the same structural position along strike (Sherwood et al., 2002).

The timing of events on land in Arctic Russia suggest that voluminous syn-extensional magmatism occurred across a broad sector of Chukotka beginning at least $117 \pm 2 \mathrm{Ma}$ ago. Reported $\mathrm{K}-\mathrm{Ar}$ ages from this region are as old as 150 (e.g. Dudkinskii et al., 1997; Akinin and Kotlyar, 1997; V. V. Akinin, personal communication, 2006) but it is difficult to evaluate the accuracy of this legacy geochronologic data. Certainly the earliest plutons in this region most likely post-date deposition of strata deposited in a basinal environment and which are as young as Valanginian $(140.2 \pm 3.0$ to 136.4 $\pm 2.0 \mathrm{Ma}$, Gradstein et al., 2004), so K-Ar ages older than 136 may be suspect. In the new Siberian Islands, nearly $1500 \mathrm{~km}$ to the west, plutons have been dated by the U-Pb method as 118 and $120 \mathrm{Ma}$ (as reported by Kos'ko and $\mathrm{Tr}$ ufanov, 2002). Accumulating evidence suggests that magmatism in the Pevek and surrounding region was associated with crustal extension and thus post-dates crustal shortening and collision-related deformation. An extension direction of ENE-WSW to NE-SW during magmatic activity is indicated by data from across a very broad region of Chukotka. Voluminous magmatism, ultimately mantle-derived (e.g. Dudkinskii et al., 1997) together with extension, likely had an important effect on the evolution of the deeper crust beneath this region, however we are still far from understanding this magmatic history. Magmatism was followed by the development of a profound regional erosional unconformity, stripping $5 \mathrm{~km}$ or more of cover from this region. This estimate is based on the suggested depth of emplacement of the granitoid bodies and is only approximate. The unconformity separates an earlier, syn-extensional period of magmatism from younger overlying rocks of the Okhotsk-Chukotsk volcanic belt that are less than $\sim 90 \mathrm{Ma}$ in the Chukotka region (Tichomirov et al., 2006). This regionally mapped unconformity on land may be correlative to the top of acoustic basement mapped across the East Siberian Shelf (e.g. Franke et al., 2004). The overlying sedimentary cover above this basal unconformity on the shelf can be tracked northwards to the shelf edge along the southern flank of the Makarov Basin (e.g. Franke et al., 2004; Sekretov, 2001) suggesting that all rifting activity had ended in the Makarov-Mendeleev Ridge part of the Amerasian Basin by the time that unconformity developed, as it is unfaulted (Sekretov, 2001). Thus we would suggest that the rift stage of opening began after the end of shortening-related deformation (post Valanginian) and was simultaneous with $\sim 120$ to 105 Ma magmatism. Subsidence and deposition on the shelf began thereafter. Figure 13 highlights the trends of bathymetrically defined structures along the flanks of the Lomonosov Ridge, in the Makarov Basin and across the Alpha-Mendeleev Ridge, which, before current ideas on the rotational opening of the Amerasian Basin, were interpreted as extensional normal faults (e.g. Taylor et al., 1981; Weber and Sweeney, 1990; summary of ideas in Secretov, 2001). Reflection seismic profiles illustrate some of these normal fault systems in detail (e.g. Forsythe and Mair, 1984; Cochran et al., 2003; Coakley et al., 2005). The bathymetric data and mapping of structures as normal faults clearly indicates an approximate N-S orientation of structures formed during E-W directed extension that is similar to trends of structures documented on land in Arctic Russia (Fig. 13). Our interpretation of the timing of this structuring of both the Makarov Basin-Mendeleev Ridge portion of the Amerasian Basin as well as the crust beneath the adjoining East Siberian Shelf is that it occurred in the Cretaceous, after $136 \mathrm{Ma}$, during the interval $120-105 \mathrm{Ma}$. This timing differs from the timing suggested initially by Taylor et al. (1981) who suggested that the Makarov Basin opened in the Late Cretaceous to Paleocene (84-49 Ma), Weber and Sweeney (1990) who suggest a broad but still young age range for seafloor spreading in the Makarov Basin (118 to $56 \mathrm{Ma}$ ) and Rowley and Lottes (1988) (between anomalies 32 and 34 (72-84 Ma)).

\section{Conclusions}

The mode of formation and the timing of development of the Amerasian Basin of the Arctic is unknown and ideas about its genesis have been debated for many years. Proponents of the rotational opening of the Amerasian Basin propose that the Lomonosov Ridge margin served as a transform plate boundary for this opening and that the AlphaMendeleev Ridge post-dates this opening and is related to hot-spot/large igneous province magmatism (e.g. Forsythe et al., 1986; Rowley and Lottes, 1988; Grantz et al., 1990a, b; Lawver et al., 2002) (Fig. 1). In this scenario, the edge of the Siberian Shelf would represent a passive rifted margin (Fig. 1). However, prior to the development of the rotation model, many workers had proposed that the Lomonosov Ridge was the rifted margin, and the Makarov Basin and Alpha-Mendeleev Ridges the consequences of orthogonal rifting from that margin. Based on refraction and reflection seismic, together with dredge sampling, Lebedeva-Ivanova 


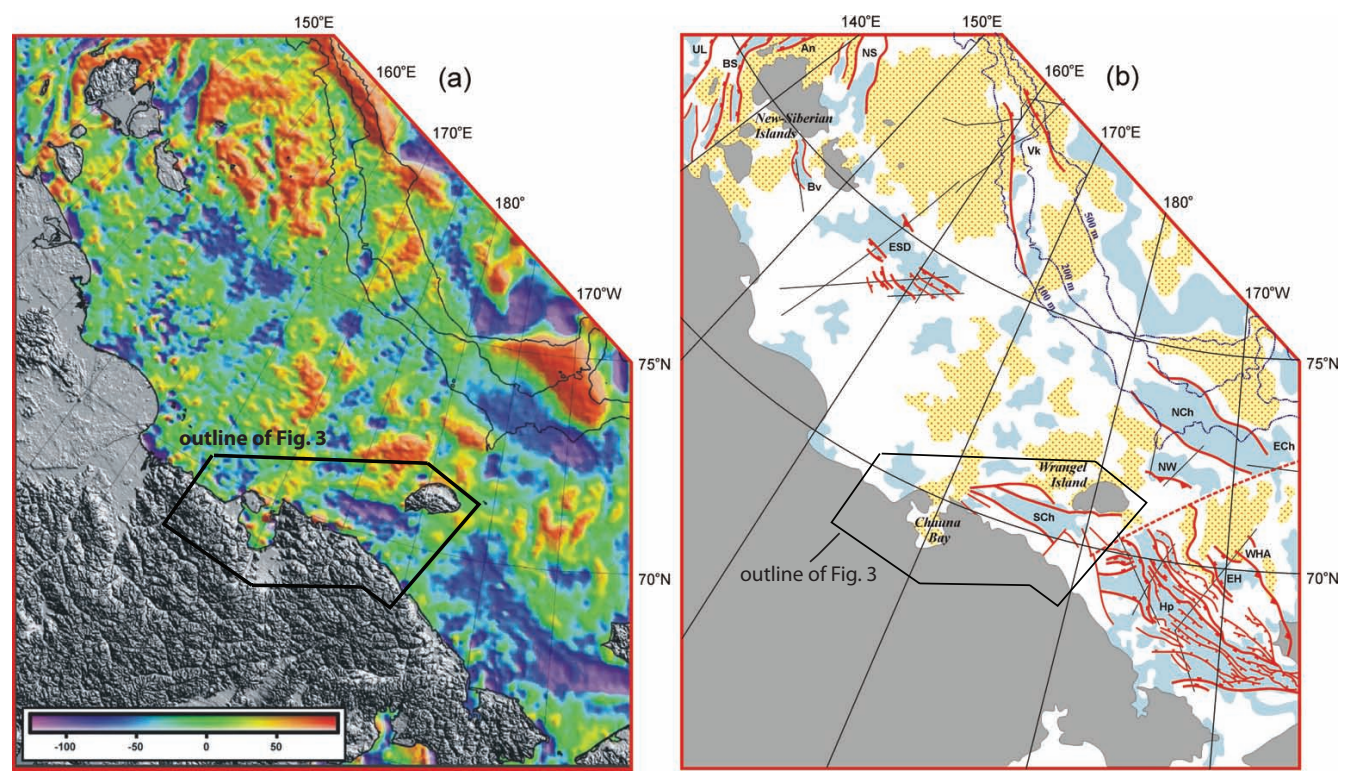

Fig. 12. Regional Compilation of Data for East Siberian Shelf: (a) Free air gravity anomaly (mGal) map of the eastern Arctic sector of the Arctic region (Laxon and McAdoo, 1994). Shown are $100 \mathrm{~m}, 200 \mathrm{~m}$, and $500 \mathrm{~m}$ depth contours in thin black lines, from Mazarovich and Sokolov (2003). (b) Regional compilation of fault and basin data for the East Siberian Shelf based on published seismic sections (locations shown by thin black lines) and satellite gravity data (Laxon and McAdoo, 1994). Red lines with squares are normal faults, with squares on downthrown side, other faults are inferred normal faults. Triangles decorate thrust faults. Blue (grey) are gravity lows and yellow (patterned grey) are highs. Abbreviations discussed in text: UL - Ust' Lena Rift, BS - Bel'kov-Svyatoi Nos Rift, An - Anisin Rift, NS - New Siberian Basin, Bv - Blagoveshchensk Basin, Vk - Vil'kitskiy Depression, ESD - East Siberian Depocenter (defined by gravity and seismic reflection), NCh - N Chukchi Basin, NW - N Wrangel Basin, Sch - South Chukchi Basin, WHA - Wrangel Herald Arch, EH - East Hope Basin, Hp - Hope Basin. Compiled from many sources including Franke et al. (2004), Mazarovich and Sokolov (2003), Sekretov (2001), Drachev et al. (1998, 2001), Grantz et al. (1990a, b), Kogan (1981), Shipilov et al. (1989) and Grantz (map in Miller et al., 2002).

et al. (2006) concluded that the Russian counterpart of the Alpha Ridge, the Mendeleev Ridge, is underlain by rifted continental crust. Our investigation of the geologic and structural history of the Arctic coast of Chukotka adds fundamental data to this controversy, and provides constraints on the timing of events onshore. It is now established that Late Jurassic-Early Cretaceous sedimentary rocks (as young as Valanginian $140 \pm 2$ to $136 \pm 2$, Gradstein et al., 2004) are involved in the last stages of crustal shortening which began in the Late Jurassic. Cretaceous magmatic activity in Chukotka occurred during a major change in tectonic regime and was accompanied by E-W to NE-SW directed extension. The age range and geochemistry of these magmas is critical to interpretations of Arctic rifting but have not at this time been studied in detail. Reported K-Ar ages are as old as $\sim 150 \mathrm{Ma}$ and as young as $85 \mathrm{Ma}$, but detailed structural studies and $\mathrm{U}-\mathrm{Pb}$ dating of zircon from a limited number of plutons including data from one of the plutons on the Pevek coast (Fig. 3), suggest a much narrower time span $\sim 108-$ $117 \mathrm{Ma}$ for this magmatic activity. Thus land-based data from Arctic Russia support a younger than 136 (end of the Valanginian stage of the Cretaceous) and older than $117 \mathrm{Ma}$ age for the inception of rifting along the Lomonosov margin of the Amerasian Basin and formation of the Makarov
Basin and Alpha-Mendeleev Ridge as a consequence of that rifting. A rift origin for these features is supported by the complex normal fault-related bathymetry of the Makarov and Alpha-Mendeleev Ridge (Fig. 13), whose trends are parallel to extension directions established in Arctic Russia. There is little evidence along this part of the Russian Arctic coast for any younger (post-plutonic) rift-related structures, faults and sedimentary basins. Because of these relations, the regional basement unconformity and relatively undisturbed overlying sedimentary cover of the Siberian Shelf may have developed during (and after) this period of regional uplift and erosion. Tectonic activity associated with formation of the Amerasian Basin had entirely ceased by the time volcanism began in the Okhotsk-Chukotka belt at about $90 \mathrm{Ma}$, when magmatism jumped south to the Pacific margin of NE Russia.

It is more difficult to extrapolate the timing relations discussed here to the region east and north of Wrangel Island including the Canada Basin part of the Amerasian Basin because of younger basin development (S. Chukchi and Hope) and the lack of reported Cretaceous plutons on Wrangel Island, for instance (Figs. 3 and 12). The main phase of rifting that opened the Canada Basin, based on interpretation of seismic stratigraphy and identification of unconformities in Canada and Alaska is inferred to be about the same age 


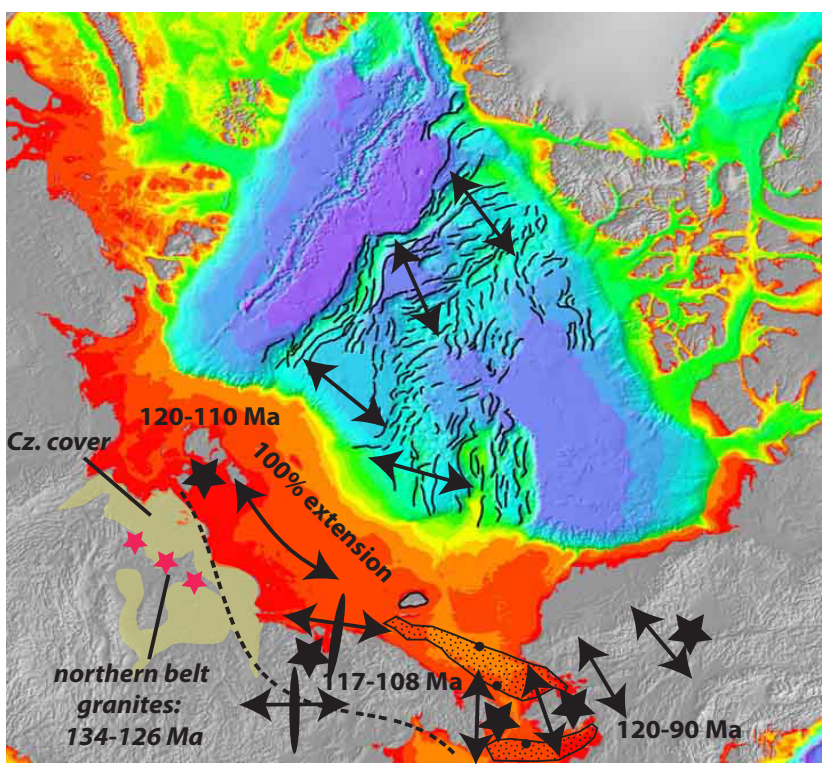

Fig. 13. The International Bathymetric Chart of the Arctic Oceans (IBCAO, 2001, available at http://www.ngdc.noaa.gov/ $\mathrm{mgg} /$ bathymetry/arctic/arctic.html) is shown as base for the Amerasian Basin to highlight the position and nature of Lomonosov Ridge, Makarov Basin and Alpha Mendeleev Ridge as well as and the Chukchi Borderland (Grantz et al., 1990a, b) . We have mapped linear normal faults associated with the basins and intrabasinal highs of the Arctic Ocean (Fig. 7a) by highlighting the steeper side of these structures. The structuring of these basins and highs is compatible with the interpretation that the Alpha and Mendeleev ridges are stretched and foundered crust rather than the locus of a younger hot spot track (Lawver and Mueller, 1994). The orientation of the various arrays of normal faults (ridges and basins) seen in the bathymetric data suggest a multi-stage and complex mode of stretching and opening of the Amerasian Basin. Black stars are Cretaceous magmatic activity and elongate ellipses are average dike orientations and inferred extension directions based on land geology (this paper). Cretaceous extension directions in northern Alaska (south flank of Brooks Range and Seward Peninsula), the Bering Strait region and adjacent Chukotka are N-S oriented and are from Miller et al. (2002). Age of northern belt granites from Toro et al. (2007).

(135-115) (e.g. Grantz et al., 1990a, b; Rowley and Lottes, 1988; Lawver et al., 2002; Embry and Dixon, 1990) leaving open the possibility that its formation was coeval with that of the rest of the Amerasian Basin. On both sides of the Bering Strait in Alaska and Russia, N-S extension documented in gneiss domes is fairly well-bracketed as syn to pre 95-90 Ma (Akinin et al., 2009). This extension direction is at right angles to that inferred for the Pevek region (Fig. 13) and is younger in age, but there is no information between these two regions (Fig. 13) that might help shed light on the transition between these two orthogonal stretching directions documented by metamorphic fabrics and dike orientations.
Acknowledgements. This research was carried out with the support of American Chemical Society-PRF Award 45432-AC8 to Elizabeth Miller. We thank Rob and Olga Smith and all of the staff of the Chukotka Mining and Geologic Company in Pevek for their tremendous help and hospitality while this project was carried out during the 17 days we waited for our helicopter flight to Wrangel Island. We thank Irina Cherepanova of the Bilibino Geological Survey who guided us on a field trip of the Jura-Triassic section. The visit of V. E. Verzhbitsky to Stanford University in 2006 for work on this project was funded by Russian Federal Agency of Science and Technology (grant \# 02.444.11.7283) with additional support and facilities provided by the Geological and Environmental Science Department and School of Earth Sciences at Stanford University and ACS-PRF. Verzhbitsky's field work in the Arctic was also supported by ONZ RAS Programs \# 6 and 14, RFBR (\# 0505-65052, and 05-05-65198), "Gazpromneft", MK-971.2005.5 and INTAS 2001-0762/F5 (NEMLOR) grants. We thank S. D. Sokolov, M. I. Tuchkova of GINRAS and L. L. Bove (Wrangel National Reserve) for helping organize the logistics of field work. We thank reviewers Mike Cecile, Steve Bergman and Jaime Toro for their helpful advice and suggestions on earlier versions of this manuscript.

\section{References}

Akimenko, G. I.: Geologic Map 1:200000 scale, R-58 XXXV, XXXVI (Bilibino), 2000.

Akinin, V. V. and Kotlyar, I. N.: GEOCHRON - a computer data base of isotopic dating of minerals, rocks and ores from the North East of Russia, Magadan, NEISRI, 202-210, 1997 (in Russian).

Akinin, V. V, Miller, E. L., and Wooden, J.: Petrology and Geochronology of crustal xenoliths from the Bering Strait region: Linking deep and shallow processes in extending continental crust, in: Crustal cross-secctions from the western North American Cordillera and elsewhere: Implications for tectonic and petrologic processes, edited by: Miller, R. B. and Snoke, A. W., Geol. Soc Am. Spec. Pap. 4XX, in press, 2009.

Baranov, M. A.: Nappe tectonics of the Myrgovaam Basin in Northwestern Central Chukotka, Geology of the Pacific Ocean, 12, 441-448, 1996.

Belik, G. Ya. and Sosunov, G. M. (Ed.): Geologic map of USSR: North-Eastern Geological Directorate, Anyuisko-Chaunskaya series, R-58-XXIX, XXX: scale 1:200 000, 1 sheet, 1969.

Bogdanov, N. A. and Til'man, S. M.: Tectonics and geodynamics of northeast of Asia (explanatory note to the tectonic map), 54 pp., 1992.

Bondarenko, G. E., Soloviev, A. V., Tuchkova, M. I., Garver, J. I., and Podgornyi, I. I.: Age of detrital zircons from sandstones of the Mesozoic flysch formation in the South Anyui suture zone (western Chukoktka), Lithol. Miner. Resour., 38(2), 162-176, 2003.

Bychkov, Yu. M. and Gorodinsky, M. E.: Comparative geology of northern Chukotka and the northern Canadian Cordillera, Proceedings, International Conference on Arctic Margins, Anchorage, Alaska, 49-53, 1992.

Cecile, M. P., Harrison, J. C., Kos'ko, M. K., and Parrish, R. R.: Precambrian $\mathrm{U}-\mathrm{Pb}$ ages of igneous rocks, Wrangel Complex, Wrangel Island USSR, Can. J. Earth Sci., 28, 1310-1348, 1991.

Coakley, B., Kristoffersen, Y., Hopper, J., Arthun, T., Berge, H., Brass, G., Breien, H., Bruvoll, V., Dove, D., Grindheim, E., 
Henkart, P., Ivanova, N., Ludvigsen, F., Monsen, K., ReynosoPeralta, W., and White, D.: A cross-Arctic geophysical transect collected from US Coast Guard Icebreaker Healy, EOS T. Am. Geophys. Un., 86(52), Fall Meet. Suppl., Abstract T13D-0510, 2005.

Cochran, J. R., Edwards, M. H., and Coakley, B. J.: Constraints on the Origin and Development of the Amerasian Basin of the Arctic Ocean from the morphology and structure of the Lomonosov Ridge, EOS T. Am. Geophys. Un., 86(52) Fall Meet. Suppl. Abst. T51E-4, 2003.

Drachev, S. S., Elistratov, A. V., and Savostin, L. A.: Structure and seismostratigraphy of the East Siberian Sea Shelf along the Indigirka Bay-Jannetta Island Seismic Profile, Trans. (Doklady) Rus. Acad. Sci./Earth Sci. Sec., 77A, 3, 293-297, 2001.

Drachev, S. S., Savostin, L. A., Groshev, V. G., and Bruni, I. E.: Structure and geology of the continental shelf of the Laptev Sea, Eastern Russian Arctic, Tectonophysics, 298, 357-393, 1998.

Dudkinskii, D. V., Kozlov, V. D., and Efremov, S. V.: PetrologicGeochemical features and geodynamic conditions of the formation of ore-bearing granitoids on the Chukchi Peninsula, Russ. Geol. Geophys.+, 38(7), 1237-1250, 1997.

Embry, A. F. and Dixon, J.: The breakup unconformity of the Amerasian Basin, Arctic Ocean: Evidence from Arctic Canada, Geol. Soc. Am. Bull., 102, 1526-1534, 1990.

Engen, Ø., Eldholm, O., and Bungum, H.: The Arctic plate boundary, J. Geophys. Res., 108(B2), 2075, doi:10.1029/2002JB001809, 2003.

Forsythe, D. A. and Mair, J. A.: Crustal structure of the Lomonosov Ridge and the Fram and the Makarov Basins near the North Pole, J. Geophys. Res., 89, 473-481, 1984.

Forsythe, D. A., Morel al'Huissier, P., Asudsen, I., and Green, A. G.: Alpha Ridge and Iceland: Products of the same plume?, J. Geodyn., 6, 197-214, 1986.

Forsythe, D. A., Asudeh, I., Green, A. G., and Jackson, H. R.: Crustal structure of the northern Alpha Ridge beneath the Arctic Ocean, Nature, London, 322, 349-352, 1986.

Franke, D., Hinz, K., and Reichert, C.: Geology of the East Siberian Sea, Russian Arctic, from seismic images: Structures, evolution, and implications for the evolution of the Arctic Ocean Basin, J. Geophys. Res., 109, B07106, doi:10.1029/2003JB002687, 2004.

Fujita, K. and Newberry, J. T.: Tectonic evolution of northeastern Siberia and adjacent regions, Tectonophysics 89, 337-357, 1982.

Fujita, K. and Cook, D. B.: The Arctic continental margin of eastern Siberia, in: The Arctic Ocean Region (A Decade of North American Geology), V. L, edited by: Grantz, A., Johnson, L., and Sweeney, J. F., Geol. Soc. Am., Boulder, CO, 289-304, 1990.

Gel'man, M. L.: Triasovaya diabasovaya formatisiya Anyuiskoi zony (Chukotka) (Triassic diabase association in the Anuy fold zone (Chukotka), Geol. Geofiz., 2, 127-134, 1963.

Gelman, M. L.: Phanerozoic granite-cored domes of the Siberian Northeast, in: Proceedings of the International Conference on Arctic Margins (Magadan, Russia, Sept. 1994), Magadan, edited by: Simakov, K. V. and Thurston, D. K., SVNTs DVO RAN, 203-209, 1995.

Glebovsky, V. Y., Kovacs, L. C., Maschenkov, S. P., and Brozena, J. M.: Joint Compilation of Russian and US Navy Aeromagnetic Data in the Central Arctic Seas, Polarforschung, 68, 35-40, 2000 .
Gorodinski, M. E.: Geologic map of northeastern Russia, Min. Geol., scale 1:1500 000, 1980.

Gradstein, F., Ogg, J., and Smith, A.: A Geologic Time Scale, Cambridge University Press, 589 pp., 2004.

Grantz, A., Eitreim, S., and Dinter, D. A.: Geology and Tectonic development of the continental margin north of Alaska, Tectonophysics, 59, 263-291, 1979.

Grantz, A., May, S. D., and Hart, P. E.: Geology of Arctic continental margin of Alaska, in: The Geology of North America, V. L, The Arctic Ocean Region., edited by: Grantz, A., Johnson, L., and Sweeney, J. F., Geol. Soc. Am., Boulder, CO, 257-288, 1990a.

Grantz, A., May, S. D., Taylor, P. T., and Lawver, L. A.: Canada Basin, in: The Geology of North America, v. L, The Arctic Ocean region, edited by: Grantz, A., Johnson, L., and Sweeney, J. F., Geol. Soc. Am., Boulder, CO, 379-402, 1990b.

Grigorev, A. I. and Paraketsov, K. B.: Geologic Map of USSR: North Eastern Geological Directorate, Anyui-Chaun Region, 1:200 000 scale, Sheet R-59-XXV-XXVI, 1962.

Gromyko, G. I. and Khruzov, L. K.: Geological map of the USSR, scale 1:200000, Quadrangles R-59-XXI-XXII, Main Dept. Geod. Cartography, Ministry Geology USSR, Moscow, 1967.

Gurevich, N. I., Merkur'ev, S. A., and Able'skaya, A. A.: Evolution of the southern part of the Canada Basin (Arctic Ocean) based on magnetometric data, Dokl. Earth Sci., 407, 308-311, 2006.

International Bathymetric Chart of the Arctic Oceans (IBCAO, 2001, available at: http://www.ngdc.noaa.gov/mgg/bathymetry/ arctic/arctic.html.

Ivanov, O. N. and Milov, A. P.: The diabase association in the Chukchi fold system and its relation to the basic magmatism in the northern portion of the Pacific Mobile Belt, in: Magmatism of North East Asia, part 2, edited by: Shatalov, E. T., Magadan Publ. House, Magadan, RU, 155-159, 1975.

Jokat, W., Uenzelmann-Neben, G., Kristoffersen, Y., and Rasmussen, T. M.: Lomonosov Ridge - A double-sided continental margin, Geology, 20, 887-890, 1992.

Jokat, W., Weigelt, E., Kristoffersen, Y., Rasmussen, T., and Schöne, T.: New geophysical results from the southwestern Eurasia Basin (Morris Jesup Rise, Gakkel Ridge, Yermak Plateau) and the Fram Strait, Geophys. J. Int., 123, 601-610, 1995.

Jokat, W.: Seismic investigations along the western sector of Alpha Ridge, Central Arctic Ocean, Geophys. J. Int., 152, 185-201, 2003.

Katkov, S. M., Miller, E. L., Podgorny, I. I., and Toro, J.: Deformation history of central Chukotka (Alarmaut Uplift) northeastern Arctic Russia, EOS AGU Trans., 85(47), Fall Meet. Suppl. Abst. GP41A-0813, 2004.

Katkov, S. M., Miller, E. L., Podgorny, I. I., and Toro, J.: Deformation history of central Chukotka (Alarmaut Uplift) northeastern Arctic Russia in, Stone, D.B., Origin of Northeastern Russia: Paleomagnetism, Geology and Tectonics, Geophysical Institute Report UAG-R-330, University of Alaska, Fairbanks, AK(CD), 2006.

Katkov, S. M., Strickland, A., Miller, E. L., Podgorny, I. I., and Toro, J.: Dating deformation in the Anyui-Chukotka fold belt, northeastern Arctic Russia, EOS Trans., 86(52), Fall Meet. Suppl. Abst. T11B-0378, 2005. 
Katkov, S. M., Strickland, A., Miller, E. L., and Toro, J.: Age of granite batholiths in the Anyui-Chukotka foldbelt, Dokl. Earth Sci., 414, 515-518, 2007.

Kogan, A. L.: Marine seismic survey in the Chukchi Sea, in: Morskiye geofizicheskiye issledovaniya v Mirovom okeane (Marine geophysical research in the World Ocean), Leningrad, Vniiokeangeologiya, 38-40, 1981 (in Russian).

Kos'ko, M. K., Cecile, M. P., Harrison, J. C., Ganelin, V. G., Khandoshko, N. V., and Lopatin, B. G.: Geology of Wrangel Island, between Chukchi and East Siberian seas, northeastern Russia, Geological Survey of Canada Bulletin, Report, 461, 101 pp. 1993.

Kos'ko, M. K., Lopatin, B. G., and Ganelin, V. G.: Major geological features of the islands of the East Siberian and Chukchi Seas and the northern coast of Chukotka, Mar. Geol., 93, 349-367, 1990.

Kos'ko, M. K and Trufanov, G. V.: Middle Cretaceous to Eopleistocene sequences on the New Siberian Islands: an approach to interpret offshore seismic, Mar. Petrol. Geol. 19, 901-919, 2002.

Krisstoffersen, Y.: Sea-floor spreading and the early opening of the North Atlantic, Earth Planet. Sc. Lett., 38, 273-290, 1978.

Lawver, L. A., Grantz, A., and Gahagan, L. M.: Plate Kinematic evolution of the present Arctic region since the Ordovician, in: Tectonic Evolution of the Bering Shelf-Chukchi Sea-Arctic Margin and Adjacent Landmasses, edited by: Miller, E. L., Grantz, A., and Klemperer, S. L., Geol. Soc. Am. S., 360, 333-358, 2002.

Lawver, L. A. and Muller, R. D.: Iceland hotspot track, Geology, 22, 311-314, 1994.

Laxon, S. and McAdoo, D.: Arctic Ocean gravity field derived from ERS-1 satellite altimetry, Science, 265, 621-624, 1994.

Lebedeva-Ivanova, N. N., Zamansky, Y. Y., Langinen, A. E., ans Sorokin, M. Y.: Seismic profiling across the Mendeleev Ridge at $82^{\circ} \mathrm{N}$ : Evidence of continental crust, Geophys. J. Int., 165, 527-544, 2006.

Marrett, R. A. and Allmendinger, R. W.: Kinematic analysis of fault slip data, J. Struct. Geol., 12, 973-986, 1990.

Mazarovich, A. O. and Sokolov, S. Yu.: Tectonic subdivision of the Chukchi and East Siberian Seas, Russ. J. Earth Sci., 5(3), 185202, 2003.

Miller, E. L., Gelman, M., Parfenov, L., and Hourigan, J.: Tectonic setting of Mesozoic magmatism: A comparison between northeastern Russia and the North American Cordillera, in: Tectonic Evolution of the Bering Shelf-Chukchi Sea-Arctic Margin and Adjacent Landmasses, editedby: Miller, E. L., Grantz, A., and Klemperer, S. L., Geol. Soc. Am. S., 360, 333-358, 2002.

Miller, E. L., Katkov, S. M., Strickland, A., Podgorny, I. I., and Toro, J.: Dating deformation in the Anyui-Chukotka fold belt, northeastern Arctic Russia, Stephan Mueller Spec. Publ. Ser., this volume, 2009.

Miller, E. L., Soloviev, A., Kuzmichev, A., Gehrels, G., Toro, J., and Tuchkova, M.: Jura-Cretaceous foreland basin deposits of the Russian Arctic: Separated by birth of Makarov Basin?, Norw. J. Geol., 88, 227-250, 2008.

Miller, E. L., Toro, J., Gehrels, G., Amato, J. M., Prokopiev, A., Tuchkova, M. I., Akinin, V. V., Dumitru, T. A., Moore, T. E., and Cecile, M. P.: New Insights into Arctic paleogeography and tectonics from U-Pb detrital zircon geochronology, Tectonics., 25, TC3013, doi:10.1029/2005TC001830, 2006.

Natal'in, B. A., Amato, J. M., Toro, J., and Wright, J. E.: Paleozoic rocks of northern Chukotka Peninsula, Russian Far East; implications for the tectonics of the Arctic region, Tectonics, 18, 977-1003, 1999.

Nokleberg, W.J. and many others: Circum-North Pacific tectonostratigraphic terrane map, US Geol. Surv. Open File Rept., 94-714, 433 pp., 2 sheets, scale 1:5000000, 2 sheets scale 1:10000 000, 1994.

Nokleberg, W. J., Parfenov, L. M., Monger, J. W. H., Norton, I. O., Khanchuk, A. I., Stone, D. B., Scholl, D. W., and Fujita, K.: Phanerozoic Tectonic Evolution of the Circum-North Pacific, US Geol. Surv. Open File Rept., 98-754, 126 pp., 1998.

Paraketsov, K. V. and Paraketsova, G. I.: Stratigraphy and fauna of Upper Jurassic and Lower Cretaceous deposits in northeast USSR, Moscow, Nedva, 297 pp., 1989.

Parfenov, L. M.: Tectonics of the Verkhoyansk-Kolyma Mesozoids in the context of plate tectonics, Tectonophysics, 199, 319-342, 1991.

Parfenov, L. M.: Accretionary history of northeast Asia, in: Proceedings of the 1994 International Conference on Arctic Margins, edited by: Thurston, D. and Fujita, K., US Dept. Interior, Minerals Management Service, Anchorage, 183-188, 1994.

Parfenov, L. M., Natapov, L. M., Sokolov, S. D., and Tsukanov, N. V.: Terrane analyses and accretion in northeastern Asia, Island Arc, 2, 35-54, 1993.

Ramsay, J. G. and Huber, M. I.: The techniques of modern structural geology, Volume One: Strain Analysis, Academic Press, London, 1983.

Rowley, D. B. and Lottes, A. L.: Plate-kinematic reconstructions of the North Atlantic and Arctic: Late Jurassic to Present, Tectonophysics 155, 73-120, 1988.

Savostin, L. A., Natapov, L. M., and Stavskiy, L.: Mesozoic paleogeodynamic and paleogeography of the Arctic region, Paleooceanology, Doklady, $27^{\text {th }}$ International Geol. Cong., Moscow, 1984, Colloquium 03, 172-187, 1984.

Sekretov, S. B.: Northwestern margin of the East Siberian Sea, Russian Arctic: seismic stratigraphy, structure of the sedimentary cover and some remarks on the tectonic history, Tectonophysics 339, 353-383, 2001.

Seslavinskiy, K. B.: The south Anyui suture (western Chukotka), Dokl. Akad. Nauk SSSR+, 249, 1181-1185, 1979 (in Russian).

Sherwood, K. W., Johnston, P. P., Craig, J. D., Zerwick, S. A., Lothamer, R. T., Thurston, D. K., and Hurlbert, S. B.: Structure and stratigraphy of the Hannah Trough, US Chukchi Shelf, Alaska, in: Tectonic Evolution of the Shelf-Chukchi Sea-Arctic Margin and Adjacent Landmasses, edited by: Miller, E. L., Grantz, A., and Klemperer, S. L., Geol. Soc. Am. S., 360, 3966, 2002.

Shipilov, E. V., Senin, B. V., and Yunov, A. Yu.: Sedimentary cover and basement of the Chukchi sea from seismic data, Geotectonics, 23, 456-463, 1989.

Sokolov, S. D., Bondarenko, G. Ye., Morozov, O. L., Ganelin, A. V., and Podgorniy, I. I.: Nappe tectonics of the South Anyui suture in the western Chukotsk Peninsula, Transactions (Doklady) of the Russian Academy of Sciences/Earth Science Section, 376(1), 7$21,2001$.

Sokolov, S. D., Bondarenko, G. Ye., Morozov, O. L., Shekhovtsov, V. A., Glotov, S. P., Ganelin, A. V., Kravchenko, B., and Berezhnoy, I. R.: South Anyui suture, Northeast Arctic Russia; facts and problems, in: Tectonic Evolution of the Shelf-Chukchi SeaArctic Margin and Adjacent Landmasses, edited by: Miller, E. 
L., Grantz, A., and Klemperer, S. L., Geol. Soc. Am. S., 360, 209-224, 2002.

Sokolov, S. D., Bondarenko, G. Ye., Layer, P. W., and KravchenkoBerezhnoy, I. R.: South Anyui suture: Tectono-stratigraphy, deformations, and principal tectonic events, Russia, Stephan Mueller Spec. Publ. Ser., this volume, 2009.

Soloviev, A., Miller, E. L. Gehrels, G., and Kuzmichev, A. B.: A statistical comparison of U-Pb detrital zircon ages from Mesozoic sandstones of the Russian Arctic, Eos Trans. AGU, 87(52), Fall Meet. Suppl., Abst. T11D-0470, 2006.

Sosunov, G. M. and Tilíman, S. M.: Geologic map of USSR: NorthEastern Geological Directorate, Anyuisko-Chaunskaya series, R58-XXXV, XXXVI, scale 1:200 000, 1 sheet, 1960.

Taylor, P. T., Kovacs, L. C., Vogt, P. R., and Johnson, G. L.: Detailed aeromagnetic investigations of the Arctic Basin, J. Geophys. Res., 86, 6323-6333, 1981.

Thurston, D. K. and Thiess, L. A.: Geologic Report for the Chukchi Sea Planning Area: Anchorage, Alaska, US Department of the Interior Minerals Management Service Outer Continental Shelf Report 87-0046, 193 pp., 1987.

Tikhomirov, P. L., Akinin, V. V., Ispolatov, V. O., Alexander, P., Cherepanova, I. Yu., and Zagoskin, V. V.: The OkhotskChukotka Volcanic Belt: Age of its northern part according to new Ar-Ar and U-Pb geochronological data, Stratigr. Geo. Correl.+, 14(5), 524-537, 2006.

Tikhomirov, P. L. and Luchitskaya, M. V.: Cretaceous granitoids of North-East Asia, Paper 1, Geol. Petrogr. Geochem., Vestnik MGU, 4(5), 13-20, 2006.
Tolson, R. B.: Structure and stratigraphy of the Hope Basin, southern Chukchi Seas, Alaska, in: Geology and resource potential of the continental margin of western North America and adjacent ocean basins: Beaufort Sea to Baja California: Houston, Texas, Circum-Pacific Council for Energy and Mineral Resources, edited by: Scholl, D. W., Grantz, A., and Vedder, J. G., Earth Science Series, 6, 59-71, 1987.

Toro, J., Prokopiev, A. V., Wiegand, B., Miller, E. L., and Wooden, J.: New U-Pb SHRIMP-RG Geochronology and Isotope Geochemistry of the Main and Northern Granitoid Belts of NE Russia, Am. Geophys. Union, Fall Meet. Abst., T13D-1574, 2007.

Tuchkova, M. I., Miller, E. L., Bondarenko, G. Y., Gehrels, G. E., Bujakaite, M. I., and Golovin, D. I.: Paleogeographical reconstruction on Triassic sedimentary basin of western Chukotka: Facial, petrographical and isotopic data, in: Sedimentary processes: Sedimentation, Lithogenesis and Ore Generation, 1, 20304, 2006 (in Russian).

Tuchkova, M. I., Sokolov, S. D., and Kravchenko-Berezhnoy, I. R.: Provenance analysis and tectonic setting of the Triassic clastic deposits in west Chukotka, NE Russia, Stephan Mueller Spec. Publ. Ser., this volume, 2009.

Weber, J. R. and Sweeney, J. F.: Ridges and basins in the Arctic Ocean, in: The Geology of North America, v. L, The Arctic Ocean Region, edited by: Grantz, A., Johnson, L., and Sweeney, J. F., Geol. Soc. America, Boulder, CO, 305-336, 1990.

Zonenshain, L. P., Kuzmin, M. I., and Natapov, L. M.: Plate Tectonics of the USSR Territory Book 2, Moscow, Nedra, 334 pp., 1990 (in Russian). 